Prepared in cooperation with Natural Resources Canada, the International Joint Commission, and the National Park Service

\title{
Network Global Navigation Satellite System Survey to Harmonize Water-Surface Elevation Data for the Rainy River Basin
}

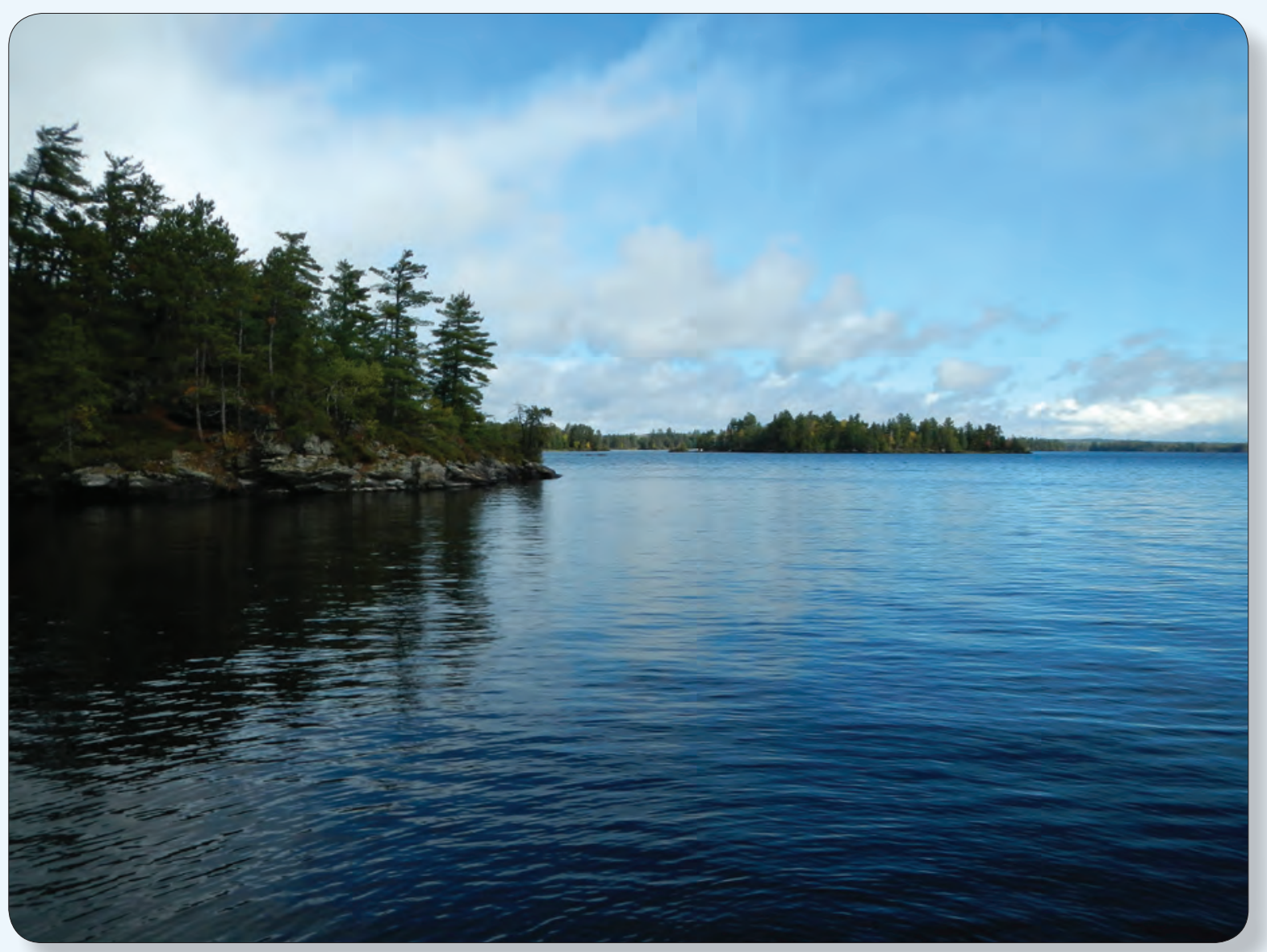

Scientific Investigations Report 2016-5109 
Front cover photograph: Namakan Lake near International Falls, Minnesota.

Back cover photograph: Rainy Lake near International Falls, Minnesota. 


\section{Network Global Navigation Satellite System Survey to Harmonize Water- Surface Elevation Data for the Rainy River Basin}

By Jeffrey R. Ziegeweid, R. Jason Silliker, Brenda K. Densmore, and Justin Krahulik

Prepared in cooperation with Natural Resources Canada, the International Joint Commission, and the National Park Service

Scientific Investigations Report 2016-5109 


\title{
U.S. Department of the Interior SALLY JEWELL, Secretary
}

\section{U.S. Geological Survey Suzette M. Kimball, Director}

\author{
U.S. Geological Survey, Reston, Virginia: 2016
}

For more information on the USGS - the Federal source for science about the Earth, its natural and living resources, natural hazards, and the environment—visit http://www.usgs.gov or call 1-888-ASK-USGS.

For an overview of USGS information products, including maps, imagery, and publications, visit http://www.usgs.gov/pubprod/.

Any use of trade, firm, or product names is for descriptive purposes only and does not imply endorsement by the U.S. Government.

Although this information product, for the most part, is in the public domain, it also may contain copyrighted materials as noted in the text. Permission to reproduce copyrighted items must be secured from the copyright owner.

Suggested citation:

Ziegeweid, J.R., Silliker, R.J., Densmore, B.K., and Krahulik, Justin, 2016, Network Global Navigation Satellite System survey to harmonize water-surface elevation data for the Rainy River Basin: U.S. Geological Survey Scientific Investigations Report 2016-5109, 20 p., http://dx.doi.org/10.3133/sir20165109.

ISSN 2328-0328 (online) 


\section{Acknowledgments}

Gail Faveri (Environment Canada) helped coordinate the joint field efforts between the United States and Canada, as well as the joint funding through the United States and Canadian offices of the International Joint Commission. Ryan Maki and Chuck Remus (Voyageurs National Park) coordinated the support of the National Park Service and logistical support to complete the field data collection. Jaime LeDuc and Claire Kissane (Voyageurs National Park) led a field crew to remote areas of Voyageurs National Park. Michael Craymer (Natural Resources Canada), Marc Véronneau (Natural Resources Canada), Jean Morin (Environment Canada), and Aaron Thompson (Environment Canada) provided input to improve the design of the survey and the presentation of the study results. Drs. Mark Colosimo and Wayne Jenkinson (International Joint Commission) approved the study and participated in regular progress reviews. Bill Odell (U.S. Army Corps of Engineers) provided reference mark and elevation data for the streamgage on Crane Lake. James Wilcox (Environment Canada) participated in field collection efforts and qualityassurance checks of collected data. Mark Schenewerk (National Oceanic and Atmospheric Administration) reviewed the report.

Chris Sanocki and Catherine Christenson of the U.S. Geological Survey participated in field data collection efforts. Scott Adolphson of the U.S. Geological Survey created the study area maps. Dave Lorenz (retired) and Jared Trost of the U.S. Geological Survey helped create and format report figures. Adam Mosbrucker of the U.S. Geological Survey reviewed the report. 


\section{Contents}

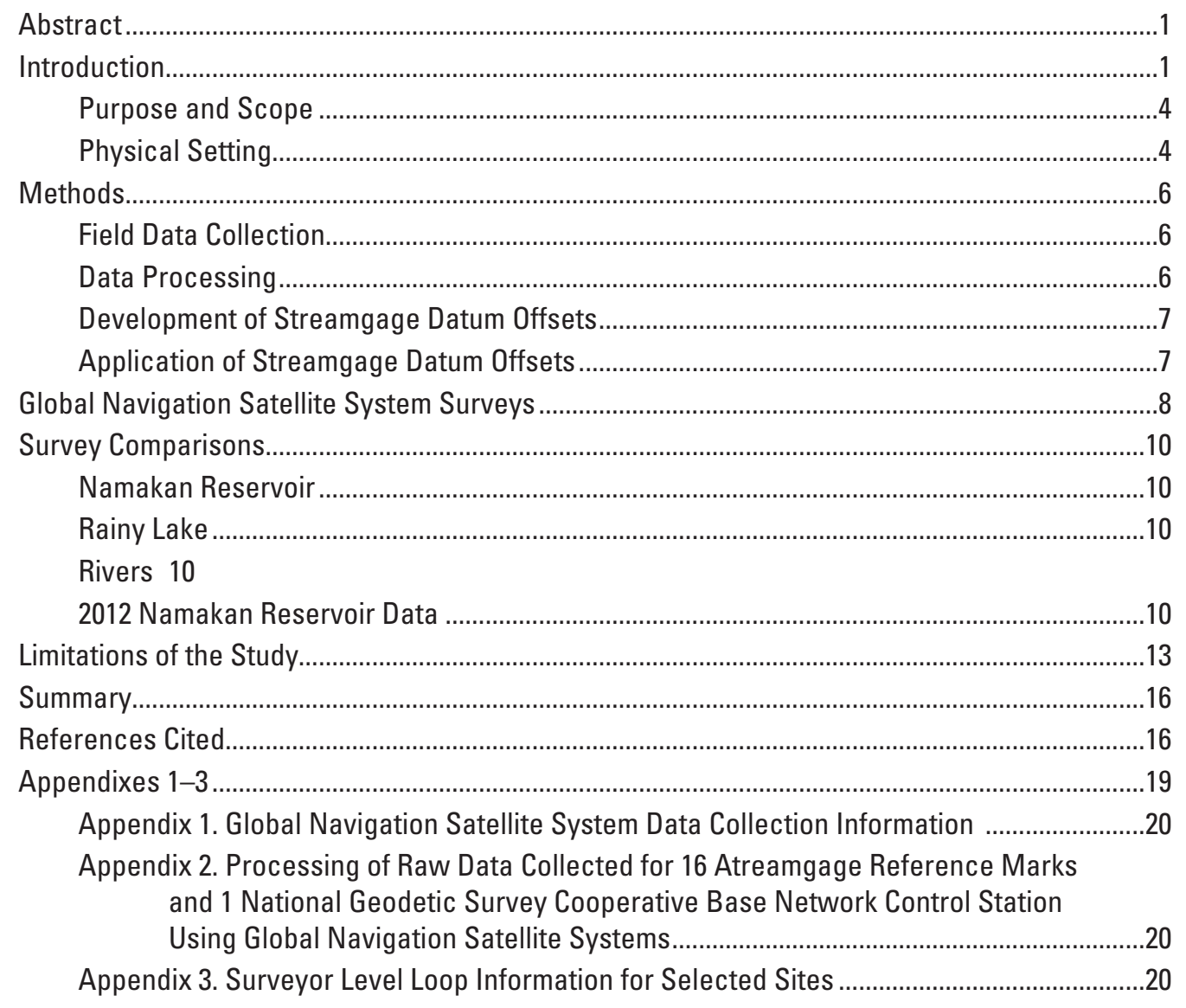

\section{Figures}

1. Maps showing water-level streamgage locations for Rainy Lake, Namakan Reservoir, and selected rivers.

2. Map showing locations of the National Geodetic Survey cooperative base network control station, Canadian Active Control Stations, and Continuously Operating Reference Stations used to postprocess data collected from global navigation satellite system receivers in this study.....

3. Graph showing water-surface elevation data referenced to the Canadian Geodetic Vertical Datum of 2013 for the data collection period at active streamgages in Namakan Reservoir, which are identified using map and station numbers associated with data in table 1 .

4. Graph showing water-surface elevation data referenced to the Canadian Geodetic Vertical Datum of 2013 for the data collection period at active streamgages in Rainy Lake, which are identified using map and station numbers associated with data in table 1 . 
5. Graph showing mean water-surface elevations referenced to the Canadian Geodetic Vertical Datum of 2013 for the data collection period at active streamgages on the Vermilion, Turtle, and Rainy Rivers; streamgages are identified using map and station numbers associated with data in table 1.

6. Graph showing monthly water-surface elevation data for all active and discontinued streamgages in Namakan Reservoir during the open water period of 2012, converted from streamgage datums to the Canadian Geodetic Vertical Datum of 2013 using offsets presented in table 4; streamgages are identified using map numbers associated with data in table 1.

7. Graph showing published mean daily water-surface elevations for discontinued U.S. Geological Survey water-level streamgages on Sand Point Lake above and below Harrison Narrows in 2012.

\section{Tables}

1. Information about streamgages in Rainy Lake, Namakan Reservoir, and selected rivers in Minnesota, Unites States, and Ontario, Canada.

2. Location information for the National Geodetic Survey cooperative base network control station, Canadian Active Control Stations, and Continuously Operating Reference Stations used to postprocess data collected from global navigation satellite system receivers in this study

3. Global Navigation Satellite System survey results for 16 streamgage reference marks and National Geodetic Survey cooperative base network control station AC4984, processed using Natural Resources Canada and U.S. Geological Survey methods.

4. Offsets to convert published water levels to water-surface elevations referenced to the Canadian Geodetic Vertical Datum of 2013 for streamgages in Rainy Lake, Namakan Reservoir, and selected rivers.

\section{Appendix Table}

1-1. Summary of collected satellite data for 16 streamgage reference marks and 1 National Geodetic Survey cooperative base network control station surveyed in this study. 
Conversion Factors

\begin{tabular}{|c|c|c|}
\hline Multiply & By & To obtain \\
\hline \multicolumn{3}{|c|}{ Length } \\
\hline millimeter (mm) & 0.03937 & inch (in.) \\
\hline meter $(\mathrm{m})$ & 3.281 & foot $(\mathrm{ft})$ \\
\hline \multicolumn{3}{|c|}{ [U.S. customary units to International System of Units] } \\
\hline \multirow[t]{2}{*}{ Multiply } & By & To obtain \\
\hline & \multicolumn{2}{|l|}{ Length } \\
\hline foot $(\mathrm{ft})$ & 0.3048 & meter $(\mathrm{m})$ \\
\hline
\end{tabular}

\section{Datum}

Vertical coordinate information is referenced to the Canadian Geodetic Vertical Datum of 2013 (CGVD2013) or North American Vertical Datum of 1988 (NAVD 88).

Horizontal coordinate information is referenced to the North American Datum of 1983 (NAD 83) or Canadian Gravimetric Geoid of 2013 (CGG2013).

Elevation, as used in this report, refers to distance above the vertical datum.

\section{Abbreviations}

$\begin{array}{ll}\text { BSW } & \text { Bernese GNSS Software v5.2 } \\ \text { CACS } & \text { Canadian Active Control System } \\ \text { CORS } & \text { Continuously-Operating Reference Station } \\ \text { CSRS } & \text { Canadian Spatial Reference System } \\ \text { EC } & \text { Environment Canada } \\ \text { GLONASS } & \begin{array}{l}\text { Global Orbiting Navigation Satellite System } \\ \text { (Russian) }\end{array} \\ \text { GNSS } & \text { Global Navigation Satellite System } \\ \text { IJC } & \text { International Joint Commission } \\ \text { NGS } & \text { National Geodetic Survey } \\ \text { NRCan } & \text { Natural Resources Canada } \\ \text { OPUS } & \text { Online Positioning Users Service } \\ \text { USACE } & \text { U.S. Army Corps of Engineers } \\ \text { USGS } & \text { U.S. Geological Survey }\end{array}$




\title{
Network Global Navigation Satellite System Survey to Harmonize Water-Surface Elevation Data for the Rainy River Basin
}

\author{
By Jeffrey R. Ziegeweid, ${ }^{1}$ R. Jason Silliker, ${ }^{2}$ Brenda K. Densmore, ${ }^{1}$ and Justin Krahulik'
}

\section{Abstract}

Continuously recording water-level streamgages in Rainy Lake and Namakan Reservoir are used to regulate water levels according to rule curves established in 2000 by the International Joint Commission; however, water levels at streamgages were referenced to a variety of vertical datums, confounding efforts to model the flow of water through the system, regulate water levels during periods of high inflow, and evaluate the effectiveness of the rule curves. In October 2014, the U.S. Geological Survey, Natural Resources Canada, International Joint Commission, and National Park Service began a joint field study with the goal of obtaining precise elevations referenced to a uniform vertical datum for all reference marks used to set water levels at streamgages throughout Rainy Lake and Namakan Reservoir. This report was prepared by the U.S. Geological Survey in cooperation with Natural Resources Canada, International Joint Commission, and National Park Service.

Three field crews deployed Global Navigation Satellite System receivers statically over 16 reference marks colocated with active and discontinued water-level streamgages throughout Rainy River, Rainy Lake, Namakan Reservoir, and select tributaries of Rainy Lake and Namakan Reservoir. A Global Navigation Satellite System receiver also was deployed statically over a National Geodetic Survey cooperative base network control station for use as a quality-control reference mark. Satellite data were collected simultaneously during a 5-day period and processed independently by the U.S. Geological Survey and Natural Resources Canada to obtain accurate positioning and elevations for the 17 surveyed reference marks. Processed satellite data were used to convert published water levels to elevations above sea level referenced to the Canadian Geodetic Vertical Datum of 2013 in order to compare water-surface elevations referenced to a uniform vertical datum throughout the study area. In this report, an "offset" refers to the correction applied to published data from a particular streamgage to produce elevation data referenced to a specified vertical datum.

${ }^{1}$ U.S. Geological Survey.

${ }^{2}$ Natural Resources Canada.
Offsets were applied to water-level data from surveyed streamgages to further evaluate the accuracy and utility of updated reference mark elevations presented in this report. Daily mean water levels from active streamgages surveyed in this study were converted to water-surface elevations referenced to the Canadian Geodetic Vertical Datum of 2013. Graphical comparisons of water-surface elevations for streamgages in Namakan Reservoir, Rainy Lake, and selected rivers are presented (referencing the Canadian Geodetic Vertical Datum of 2013). Offsets presented in this report can be used in the evaluation of rule curves and in flood damage curves that fully assess the benefits of one regulation approach over another. In addition, offsets may be used to calibrate hydraulic models developed for four narrows that connect lakes of Namakan Reservoir, refine digital elevation models, and support modeling studies designed to assess the effects of rule curves on aquatic vegetation, benthic invertebrates, northern pike, and walleye.

\section{Introduction}

The Rainy River Basin of northern Minnesota and southwestern Ontario is a complex system of lakes and rivers (Kallemeyn and others, 2003), including Namakan Reservoir, Rainy Lake, and several rivers that feed these lake systems (fig. 1). Namakan Reservoir includes Crane, Little Vermilion, Sand Point, Kabetogama, and Namakan Lakes. Rainy Lake drains into the Rainy River near the towns of Fort Frances, Ontario, and International Falls, Minnesota. Rainy River, the southern basin of Rainy Lake, and Namakan Reservoir form the international border between the United States and Canada.

Water levels in Rainy Lake and Namakan Reservoir are managed according to rule curves established by the International Joint Commission (IJC) with the assistance of the International Rainy Lake Board of Control (International Rainy Lake Board of Control, 1999). Rule curves established in 2000 (hereafter referred to as the 2000 Rule Curves) set maximum and minimum allowable water levels on an annual basis (Kallemeyn and others, 2003). The 2000 Rule Curves 


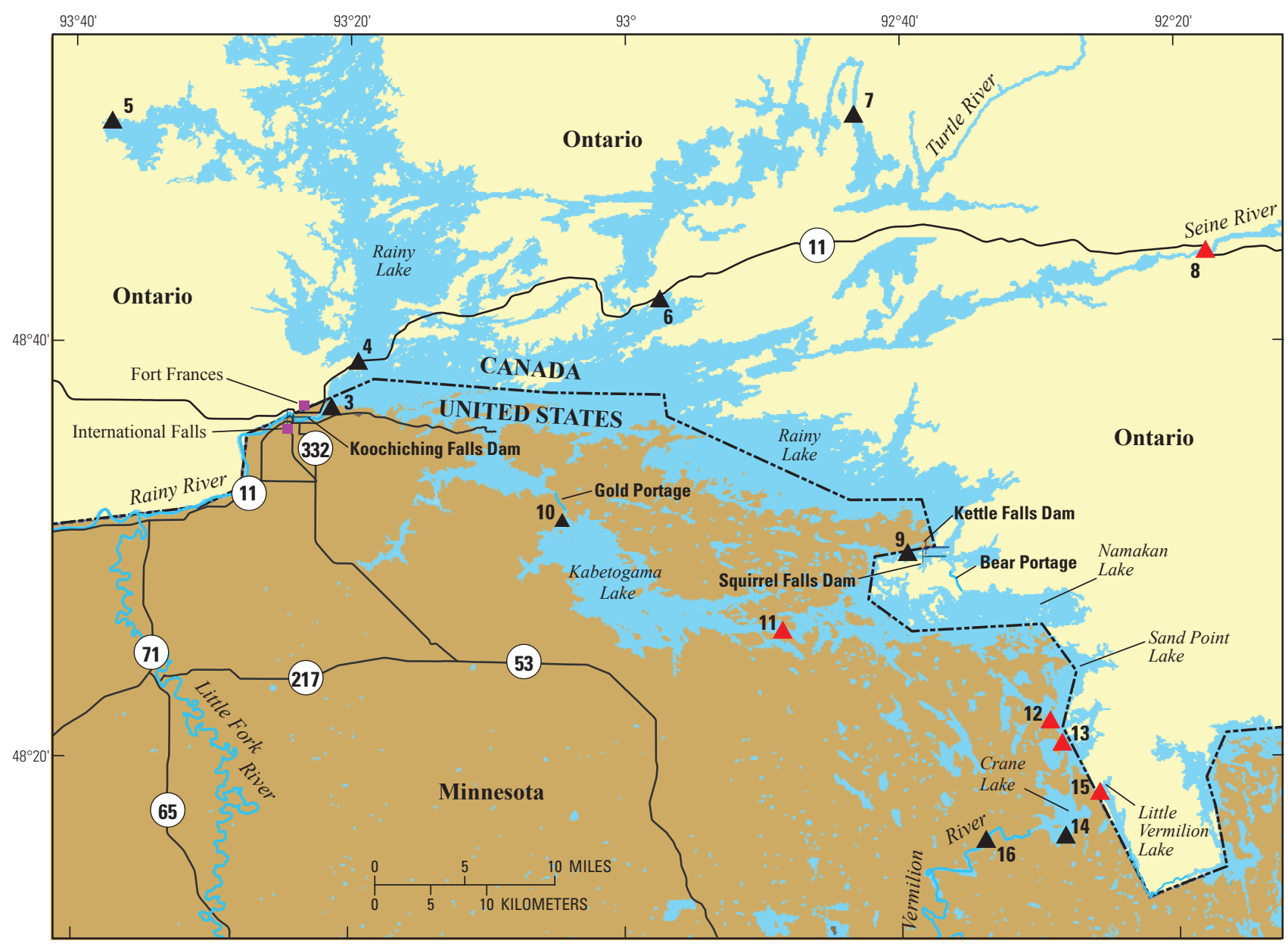

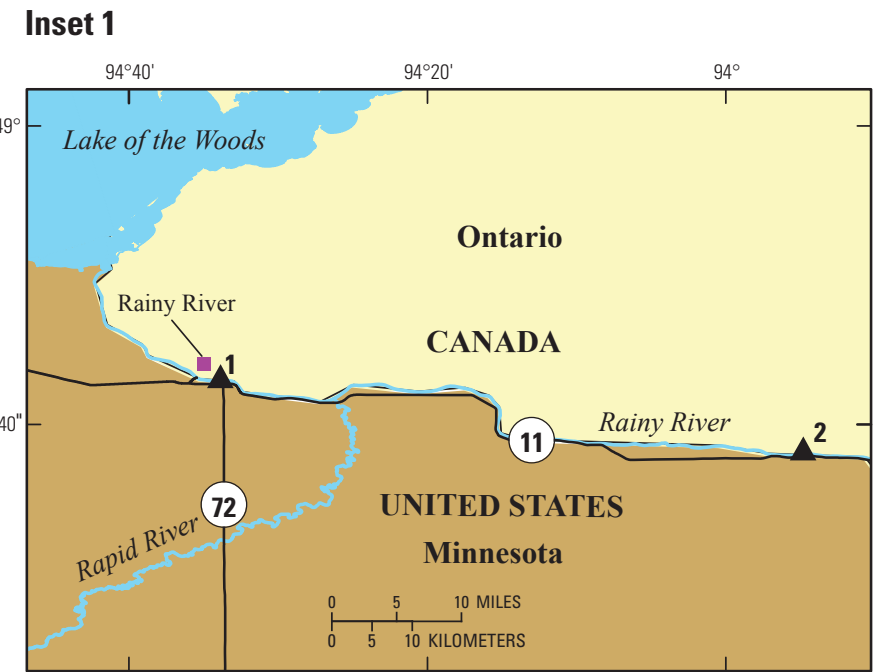

Inset 2

\section{EXPLANATION}

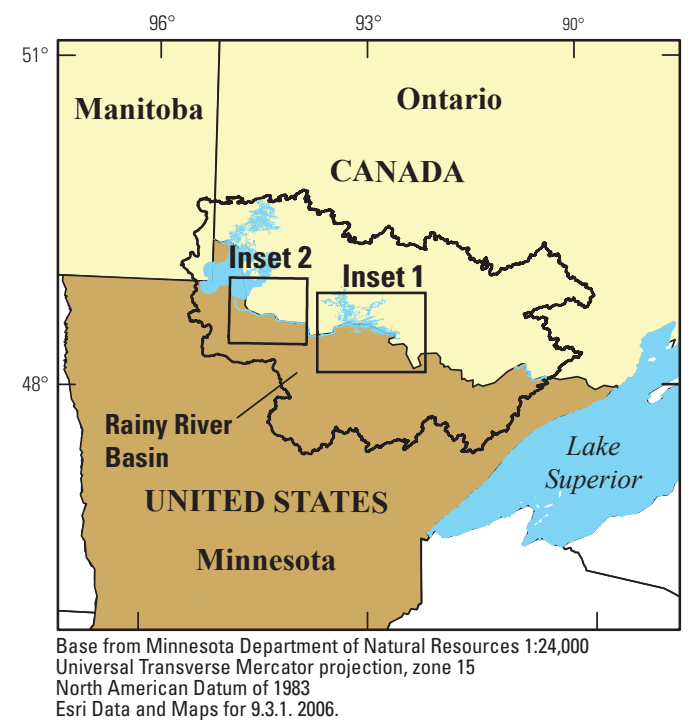

1. Active streamgage with map number (table 1)

16. Discontinued streamgage with map number (table 1)

Figure 1. Water-level streamgage locations for Rainy Lake, Namakan Reservoir, and selected rivers. 
account for natural seasonal fluctuations in water level while balancing the requirements for several legally recognized water uses within the basin (Kallemeyn and others, 2003). Streamgages throughout Rainy Lake and Namakan Reservoir (fig. 1) are used to monitor water levels for compliance with the 2000 Rule Curves; however, monitoring has been complicated because water-surface elevations at these streamgages are referenced to several different vertical datums (table 1). In this report, "elevation" will refer to a measurement or height relative to a specified datum. Without comparable elevation data, water-resource managers cannot develop accurate digital elevation models or hydraulic models that describe the movement of water through the basin (Densmore and others, 2013; Stevenson and Thompson, 2013); furthermore, during periods of high inflow, water levels in the lower Namakan Reservoir may differ from water levels in the upper Namakan Reservoir by as much as 0.3 meter $(\mathrm{m})$, creating situations in which the lower part of the reservoir are within the rule curve band, whereas the upper part of the reservoir is well above the rule curve band. Therefore, obtaining accurate and precise elevation data referenced to a single vertical datum is critical to understanding and managing water levels in Rainy Lake and Namakan Reservoir.

In October 2014, the U.S. Geological Survey (USGS), Natural Resources Canada (NRCan), IJC, and National Park Service began a joint field study with the goal of obtaining precise elevations referenced to a uniform vertical datum for all reference marks used to set water levels at streamgages

Table 1. Information about streamgages in Rainy Lake, Namakan Reservoir, and selected rivers in Minnesota, Unites States, and Ontario, Canada.

[EC, Environment Canada; LOW, Lake of the Woods Vertical Datum; USGS, U.S. Geological Survey; NGVD 1929, National Geodetic Vertical Datum of 1929; NA, seasonal biological site — data not publicly accessible; Assumed datum, arbitrary elevation used to set water levels at streamgages; SRFN, Seine River First Nation; USC \& GS 1912; United States Coast and Geodetic Survey Datum of 1912; NAVD 88, North American Vertical Datum of 1988; MSL 1912, Mean Sea Level datum of 1912;]



${ }^{1}$ Station only operated during open-water periods. 
throughout Rainy Lake and Namakan Reservoir. In this study, the USGS and NRCan used geodetic-quality global navigation satellite system (GNSS) receivers to complete simultaneous static surveys on 16 streamgage reference marks and 1 National Geodetic Survey cooperative base network control station in the Rainy River, Rainy Lake, Namakan Reservoir, and tributaries of Rainy and Crane Lakes using established methodologies (Canadian Geodetic Survey, 2003, 2013; Rydlund and Densmore, 2012).

The objective of this study was to obtain precise elevations referenced to the Canadian Geodetic Vertical Datum of 2013 (CGVD2013) for 16 streamgage reference marks used to establish water levels at streamgages throughout the Rainy River Basin (table 1). In total, 11 of the reference marks were used to establish water levels for active streamgages that provide real-time, continuous water-level data; 5 of the reference marks surveyed were used to establish water levels for discontinued, temporary streamgages operated during previous studies. Discontinued streamgages used transducers that recorded changes in water levels by measuring changes in the pressure and temperature of the water surrounding the transducer. Three of the four discontinued, temporary streamgages only operated during open-water periods. Active streamgages are operated by the USGS, U.S. Army Corps of Engineers (USACE), and Environment Canada (EC). The final reference mark surveyed was National Geodetic Survey (NGS) cooperative base network control station AC4984 (map number 17), a reference mark of known elevation that was used as a qualitycontrol reference mark (table 2; fig. 2).

\section{Purpose and Scope}

This report was prepared by the USGS in cooperation with NRCan, the IJC, and the National Park Service. The purposes of this report are to (1) describe the field surveys used to collect GNSS data for 17 reference marks in the Rainy River Basin (fig. 1), (2) describe how GNSS data were processed to determine water-surface elevations for all streamgages surveyed in this study, (3) present corrections to convert waterlevel data previously collected at the streamgages to watersurface elevations referenced to a uniform vertical datum, and (4) outline factors to consider when applying corrections to previously collected water-level data. The study is limited to the 16 streamgages in the Rainy River Basin associated with reference marks that were surveyed in this study; however, additional studies could expand the scope of this study to include additional tributary streamgages within the Rainy River Basin. In addition, a similar approach could be used in other basins that have streamgages referenced to a variety of vertical datums.

\section{Physical Setting}

The study area includes the Rainy, Turtle, Seine, and Vermilion Rivers; Rainy Lake; and the five lakes that compose Namakan Reservoir: Crane, Little Vermilion, Sand Point, Kabetogama, and Namakan Lakes (fig. 1). The Vermilion River flows into Crane Lake at the upper end of Namakan Reservoir. Crane and Little Vermilion Lakes flow into Sand Point

Table 2. Location information for the National Geodetic Survey cooperative base network control station, Canadian Active Control Stations, and Continuously Operating Reference Stations used to postprocess data collected from global navigation satellite system receivers in this study

[Station ID, alpha-numeric descriptor assigned to each station; NGS, National Geodetic Survey cooperative base network control station; CACS, Canadian Active Control Station; CORS, Continuously Operating Reference Station]

\begin{tabular}{|c|c|c|c|c|c|}
\hline $\begin{array}{c}\text { Map } \\
\text { number } \\
\text { (fig. 2) }\end{array}$ & Station ID & Station location & Type of station & $\begin{array}{c}\text { Latitude } \\
\text { (degree/minute/ } \\
\text { second) }\end{array}$ & $\begin{array}{c}\text { Longitude } \\
\text { (degree/minute/ } \\
\text { second) }\end{array}$ \\
\hline 17 & AC4984 & Crane Lake, Minnesota & NGS & N 481509.72616 & W 922914.96555 \\
\hline 18 & ALGO & Algonquin Park, Ontario & CACS & N 455720.84731 & W 780416.90648 \\
\hline 19 & DUBO & Lac Du Bonnet, Manitoba & CACS & N 501531.68253 & W 955158.20777 \\
\hline 20 & FLIN & Flin Flon, Manitoba & CACS & N 544332.07415 & W 1015840.86832 \\
\hline 21 & PICL & Pickle Lake, Ontario & CACS & N 512847.27895 & W 900943.06934 \\
\hline 22 & GDMA & Grand Marais, Minnesota & CORS & N 474454.75711 & W 902028.47144 \\
\hline 23 & MNAS & Ash Lake, Minnesota & CORS & N 481738.54626 & W 925813.42650 \\
\hline 24 & MNBD & Birchdale, Minnesota & CORS & N 483739.67691 & W 940402.15729 \\
\hline 25 & MNMG & Margie, Minnesota & CORS & N 480804.54490 & W 935242.50778 \\
\hline 26 & MNRV & Roosevelt, Minnesota & CORS & N 484721.79724 & W 950304.45950 \\
\hline 27 & MNSQ & Squaw Lake, Minnesota & CORS & N 473613.44132 & W 940736.20907 \\
\hline 28 & MNVI & Virginia, Minnesota & CORS & N 473123.77164 & W 923341.43356 \\
\hline 29 & MNWH & Waskish, Minnesota & CORS & N 480900.63600 & W 943042.99689 \\
\hline 30 & ROSS & Rossport, Ontario & CORS & N 485001.39381 & W 873110.52238 \\
\hline 31 & YWG1 & Winnipeg, Manitoba & CORS & N 495402.06942 & W 971533.82364 \\
\hline
\end{tabular}




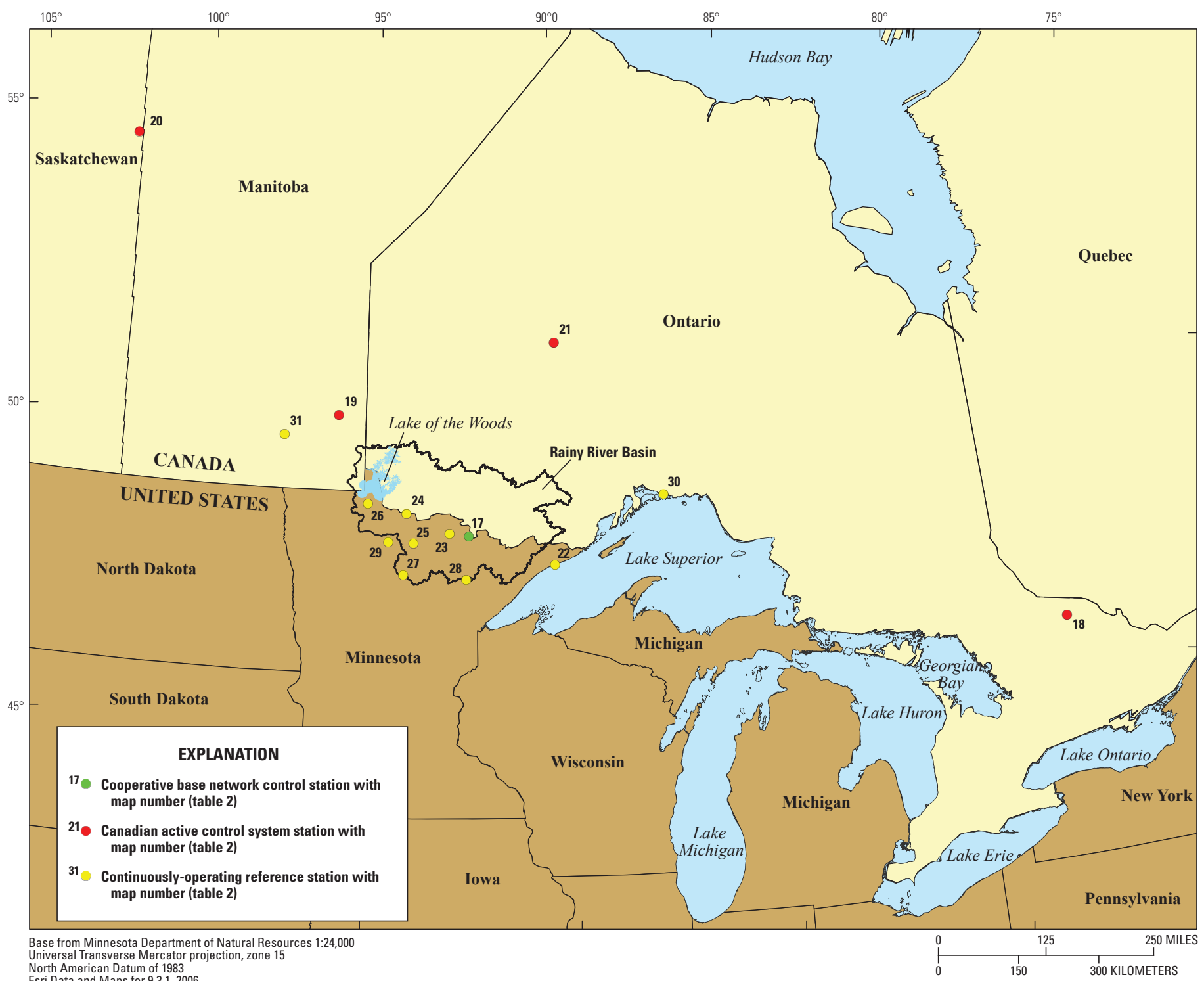

Figure 2. Locations of the National Geodetic Survey cooperative base network control station, Canadian Active Control Stations, and Continuously Operating Reference Stations used to postprocess data collected from global navigation satellite system receivers in this study.

Lake; Sand Point Lake flows into Namakan Lake; and water moves bidirectionally between Namakan and Kabetogama Lakes depending on lake levels, wind direction, inflows from tributaries, and dam regulation (Christensen and others, 2013). Water flows from Namakan and Kabetogama Lakes into Rainy Lake from outflows at Kettle and Squirrel Falls Dams and at Gold Portage outlet, respectively. Rainy Lake is fed by Namakan Reservoir and several tributary rivers. The Seine and Turtle Rivers are the two largest tributaries that enter Rainy Lake downstream from the outflows from Namakan Reservoir into Rainy Lake (Kallemeyn and others, 2003). Rainy Lake drains into Rainy River at the southwestern corner of Rainy Lake, and the Rainy River flows northwest into Lake of the Woods. Rainy River, the southern basin of Rainy Lake, and
Namakan Reservoir form the international border between the United States and Canada.

Water levels in Rainy River, Rainy Lake, and Namakan Reservoir are controlled by three dams. The Koochiching Falls Dam controlling Rainy River flow out of Rainy Lake is located between Fort Frances, Ontario, and International Falls, Minnesota. This dam is the source of hydroelectric power for the Boise Cascade Corporation's paper pulp industrial facilities. Two dams control the flow of water from Namakan Lake into Rainy Lake: Kettle Falls and Squirrel Falls Dams (International Rainy Lake Board of Control, 1999). The parts of Kettle Falls and Koochiching Falls Dams located in the United States are owned by the Boise Cascade Corporation, and the Canadian part is owned by Abitibi Consolidated Incorporated. 
Network Global Navigation Satellite System Survey to Harmonize Water-Surface Elevation Data

In addition to the regulated outflows at Kettle and Squirrel Falls, overflows from Namakan Lake into Rainy Lake happen at Bear and Gold Portages.

\section{Methods}

Methods are described in the following four sections of this report. The first section details how GNSS receivers were deployed and how field data were collected. The second section details the processing methods used by NRCan and USGS to obtain elevations for the surveyed reference marks. All elevations reported in the second section were measured to the nearest $0.001 \mathrm{~m}$. The third section describes how elevations of reference marks were used to develop offsets, which are values added to or subtracted from published water levels in order to convert water-level data to elevations referenced to CGVD2013. The fourth section details how offsets were applied to published water levels and how corrected elevations were used to compare and evaluate collected water-level data from streamgages throughout the study area.

\section{Field Data Collection}

Three field crews deployed 17 geodetic-quality global positioning system GNSS receivers paired with choke ring antennas statically for satellite data collection. The GNSS units for data collection were deployed from October 5, 2014 (day of year 278), through October 9, 2014 (day of year 282), at 16 specified streamgage locations (fig. 1) and 1 NGS cooperative base network control station (map number 17; fig. 2) for additional quality assurance. The exact start and end dates and times for each GNSS unit are available electronically in table 1-1 of appendix 1; GNSS units were deployed to provide as much simultaneous data collection time as possible among all surveyed sites and minimize variability related to weather conditions and satellite positions. The log files from the GNSS surveys are available electronically in appendix 1.

Field data-collection procedures used during the survey followed guidelines established for static network surveys as described by compatible methods from NRCan (Canadian Geodetic Survey, 2003, 2013) and the USGS (Rydlund and Densmore, 2012). When a clear view of surrounding satellites was possible, GNSS units were deployed directly above existing reference marks used to establish water levels at streamgages; however, at locations where a clear view of surrounding satellites was obstructed by tree cover or topographical relief, GNSS units were deployed nearby to improve the quality of satellite signal reception and reduce satellite signal multipath. Multipath is a condition in which the accuracy of collected satellite data diminishes because the satellite signal arrives at the receiver antenna by way of several different paths (Georgiadou and Kleusberg, 1988). Bodies of water can create reflective surfaces that cause multipath issues. For view-obstructed locations where reference marks could not be surveyed directly, surveyor level loops (also referred to as spirit level circuits) were used to accurately measure elevation differences between points surveyed with GNSS and streamgage reference marks (Kenney, 2010; Canadian Geodetic Survey, 2013). Instantaneous water levels were obtained at each site using either readings from operating streamgages (Environment Canada, 2015; U.S. Army Corps of Engineers, 2015; U.S. Geological Survey, 2015) or direct measurement from an established reference mark using surveyor level loops.

\section{Data Processing}

Elevations as defined by ellipsoid, geoid, and orthometric heights are all attempts to model the shape of the Earth using real world coordinates. An ellipsoid is a spherical shape with a polar radius that is shorter in length than the equatorial radius, and the overall shape of the Earth is best predicted using an ellipsoid (Li and Götze, 2001). Ellipsoid heights are offsets above or below a reference ellipsoid. A geoid is a model that represents the Earth's mean global sea level under the influence of gravitation and rotation alone (Milbert and Smith, 1996), and each vertical datum is associated with a particular geoid. Geoid heights are applied to ellipsoid heights to obtain orthometric heights, which refer to elevations above sea level referenced to the vertical datum associated with the geoid model.

The GNSS data collected at control and reference stations (fig. 2; table 2) were used to determine three-dimensional coordinates (latitude, longitude, and ellipsoid heights). Both NRCan and USGS postprocessed GNSS data were collected in receiver independent exchange (also known as RINEX) format independently using different methods in order to provide a quality comparison. The horizontal reference frames used by Canada (North American Datum of 1983 [NAD 83]; Canadian Spatial Reference System [CSRS]) and the United States (NAD 83 [2011] reference frame in epoch 2010.00) are compatible and equivalent for the purposes of this study.

Satellite data were processed by NRCan staff using Bernese GNSS Software v5.2 (BSW; Dach and others, 2007; Dach and Walser, 2015), a relative positioning method whereby coordinated differences between pairs of points (baselines) are computed. Although BSW is capable of processing data from the Russian Global Orbiting Navigation Satellite System (GLONASS), the GLONASS data were not processed in this study. Using BSW, three-dimensional coordinates (latitude, longitude, and ellipsoid heights) were determined for the 16 streamgage reference marks and NGS cooperative base network control station AC4984 in the geometric reference frame of NAD 83 (CSRS) Velocity Grid v6 for epoch 2010.0.

Data from four Canadian Active Control System (CACS; Natural Resources Canada, 2016) stations were included to provide a connection to the NAD 83 reference frame and the international terrestrial reference frame (also known as ITRF) in order to obtain specific coordinates (table 2); the CACS 
stations included ALGO (Algonquin Park, Ontario), DUBO (Lac Du Bonnet, Manitoba), FLIN (Flin Flon, Manitoba), and PICL (Pickle Lake, Ontario). Seven other CACS stations and NGS Continuously Operating Reference Stations (CORS; National Geodetic Survey, 2014a) were included as local quality-control points; however, a substantial part of available data from these stations could not be used because signal obstructions prohibited common satellites from being in view at both ends of the baseline, and these seven stations were not used in the study.

Session baselines from BSW were corrected for relative crustal motion between the observation epoch and the 2010.0 reference epoch using the adopted NAD 83 (CSRS) Velocity Grid v6 (Craymer and others, 2011). Such crustal motions between local stations and CACS stations that are much farther away can substantially affect reference frame realization. Estimated session baselines were combined into a network adjustment using NRCan GHOST software (Beattie, 1987), and CACS stations were weighted to known NAD 83 (CSRS) Velocity Grid v6 coordinates at epoch 2010.0 using known accuracies. The Canadian Gravimetric Geoid model of 2013 (CGG2013) was applied to postprocessed ellipsoid heights to obtain orthometric heights referenced to CGVD2013 for all streamgage reference marks and NGS cooperative base network control station AC4984 (Huang and Véronneau, 2013; Véronneau and others, 2014a, 2014b).

The USGS postprocessed the GNSS data through the NGS Online Positioning Users Service (OPUS; National Geodetic Survey, 2014b), a service that uses the NGS PAGES processing software (National Geodetic Survey, 2015a), with baseline processing methodology similar to BSW. Using OPUS-Projects (National Geodetic Survey, 2014c), a network adjustment was applied to the 16 streamgage reference marks and NGS cooperative base network control station AC4984 using 10 CORS to define the NAD 83 (2011) reference frame in epoch 2010.0 (table 2); the CORS used in the network adjustment included GDMA (Grand Marais, Minnesota), MNAS (Ash Lake, Minn.), MNBD (Birchdale, Minn.), MNMG (Margie, Minn.), MNRV (Roosevelt, Minn.), MNSQ (Squaw Lake, Minn.), MNVI (Virginia, Minn.), MNWH (Waskish, Minn.), ROSS (Rossport, Ontario), and YWG1 (Winnipeg, Manitoba; National Geodetic Survey, 2014a).

Using OPUS, the USGS established known geodeticquality coordinates for each reference mark (Rydlund and Densmore, 2012); coordinate information for each reference mark includes NAD 83 (2011 epoch 2010.00), latitude, longitude, and ellipsoid heights (National Geodetic Survey, 2012). Geoid model 12A (National Geodetic Survey, 2015b) was applied to postprocessed ellipsoid heights to obtain orthometric heights referenced to the North American Vertical Datum of 1988 (NAVD 88; Zilkoski and others, 1992); however, after processing session baselines, more than one-half of the available data were omitted by OPUS based on automated data quality criteria established by the NGS. As a result, as little as 13 hours of data were used to process session baselines for some reference marks. In addition, the CORS of MNAS,
MNBD, MNMG, MNRV, MNSQ, and MNWH have modeled velocities that do not include vertical velocities; therefore, corrections for vertical crustal motion cannot be applied uniformly across the area covered by the CORS for data processed in OPUS-Projects by the USGS. In contrast, processing completed by NRCan using BSW included corrections for vertical crustal motion applied to all processed baselines and estimated coordinates.

\section{Development of Streamgage Datum Offsets}

Orthometric heights obtained from processing collected GNSS data were used to develop offsets that convert published water levels to elevations referenced to CGVD2013, either through direct streamgage reference mark surveys or surveyor level loops between surveyed points and streamgage reference marks. Offsets are based on published water levels, so the magnitude of each offset depends on whether water levels are published as actual elevations or as local datums that allow smaller numbers to be used for publication. For example, USGS station 05129290 (Gold Portage outlet from Kabetogama Lake near Ray, Minnesota; map number 10) (fig. 1) was established using the U.S. Coast and Geodetic Survey Datum of 1912; however, water levels are published as elevations minus 1,100 feet (U.S. Geological Survey, 2015). The offset for USGS station 05129290, therefore, will be much larger compared to the offset for USACE station CNLM5 (Crane Lake at Crane Lake, Minnesota; map number 14) (fig. 1), which are published as elevations in 1912 Mean Sea Level datum (U.S. Army Corps of Engineers, 2015). Offset data are presented in metric (International System) and English (U.S. customary) units. The vertical datums used to establish water levels for streamgages examined in this study are presented in table 1 .

\section{Application of Streamgage Datum Offsets}

Streamgage datum offsets were applied to surveyed streamgages, and water-surface elevations referenced to CGVD2013 were compared among active streamgages in Namakan Reservoir; Rainy Lake; and the Vermilion, Turtle, and Rainy Rivers (fig. 1). In addition, because three of the four temporary streamgages in the Namakan Reservoir were only operated during open water periods between the start and end dates shown in table 1, the period from May 1, 2012, through September 30, 2012, was used to compare water-surface elevations among all active and discontinued streamgages in Namakan Reservoir. This period represents the most recent period when all active and discontinued streamgages in Namakan Reservoir operated simultaneously. Monthly mean water-surface elevations (referenced to CGVD2013) were compared among all streamgages in Namakan Reservoir in order to average variability in the data associated with the temporary streamgage installations. 


\section{Global Navigation Satellite System Surveys}

Deployment times for GNSS units ranged from 29 to 68 hours, with a mean deployment time of 46 hours. Satellite data quality was generally good during the GNSS surveys. Despite the best efforts of the field crews to find locations with a clear view of surrounding satellites, steep terrain and dense tree cover surrounding some of the streamgage locations interfered with satellite coverage during certain times of the day. In addition, proximity of the GNSS units to the water surface created multipath issues that had to be accounted for during data processing. Surveyor level loops between GNSS survey points and reference marks of known elevation referenced to a specified vertical datum likely introduced a small amount of error (less than or equal to $0.005 \mathrm{~m}$ ) into the elevation data.

Comparisons of water-surface elevations at surveyed streamgages only will be presented in metric units (meters). Data processing files are included in appendix 2. The measured ellipsoid and orthometric heights of 17 survey locations processed using NRCan and USGS methods are presented in table 3. Surveyor level loop information between GNSSsurveyed points and streamgage reference marks are in appendix 3.

The NAD 83 ellipsoid heights obtained using NRCan and USGS processing methods closely approximated each other (table 3 ) even though the USGS did not apply corrections for

Table 3. Global Navigation Satellite System survey results for 16 streamgage reference marks and National Geodetic Survey cooperative base network control station AC4984, processed using Natural Resources Canada and U.S. Geological Survey methods.

[NRCan, Natural Resources Canada; USGS, U.S. Geological Survey; Ellipsoid height, offsets above or below a reference ellipsoid that represents the shape of the Earth; m, meter; CGG2013, correction for the Canadian Gravimetric Geoid of 2013 applied to ellipsoid heights to obtain elevations referenced to the Canadian Geodetic Vertical Datum of 2013 (CGVD2013); Orthometric height, elevation above sea level referenced to the vertical datum corresponding to the applied geoid; 12A, elevation correction for Geoid 12A applied to ellipsoid heights to obtain elevations referenced to the North American Vertical Datum of 1988 (NAVD 88); no., number]

\begin{tabular}{|c|c|c|c|c|c|c|c|c|}
\hline \multirow{2}{*}{$\begin{array}{c}\text { Map } \\
\text { number } \\
\text { (figs. 1 } \\
\text { and 2) }\end{array}$} & \multirow[b]{2}{*}{ Station number } & \multirow[b]{2}{*}{ Station name } & \multicolumn{3}{|c|}{ NRCan } & \multicolumn{3}{|c|}{ USGS } \\
\hline & & & $\begin{array}{l}\text { Ellipsoid } \\
\text { height } \\
\text { (m) }\end{array}$ & $\begin{array}{l}\text { CGG2013 } \\
(\mathbf{m})\end{array}$ & $\begin{array}{l}\text { Orthometric } \\
\text { height }{ }^{1} \\
\text { (m) }\end{array}$ & $\begin{array}{l}\text { Ellipsoid } \\
\text { height } \\
\text { (m) }\end{array}$ & $\begin{array}{l}12 A \\
(m)\end{array}$ & $\begin{array}{l}\text { Orthometric } \\
\text { height }{ }^{2} \\
\text { (m) }\end{array}$ \\
\hline 1 & 05PC021 & Rainy River at Rainy River & 296.952 & 28.295 & 325.247 & 296.959 & 29.077 & 326.036 \\
\hline 2 & 05133500 & $\begin{array}{l}\text { Rainy River at Manitou Rapids, } \\
\text { Minnesota }\end{array}$ & 311.001 & 29.028 & 340.029 & 310.998 & 29.792 & 340.790 \\
\hline 3 & 05РC024 & Rainy River at Pithers Point site no. 1 & 307.964 & 30.013 & 337.977 & 307.972 & 30.817 & 338.789 \\
\hline 4 & 05РB007 & Rainy Lake near Fort Frances & 309.039 & 30.130 & 339.169 & 309.041 & 30.920 & 339.961 \\
\hline 5 & 05РВ023 & Rainy Lake at Northwest Bay & 307.412 & 29.962 & 337.374 & 307.424 & 30.743 & 338.167 \\
\hline 6 & 05РB024 & Rainy Lake near Bear Pass & 306.839 & 30.796 & 337.635 & 306.848 & 31.561 & 338.409 \\
\hline 7 & 05РB014 & Turtle River near Mine Centre & 315.727 & 31.302 & 347.029 & 315.714 & 32.062 & 347.776 \\
\hline 8 & SRFN1 & Seine River biological site & 307.101 & 31.636 & 338.737 & 307.110 & 32.374 & 339.484 \\
\hline 9 & 05РA013 & Namakan Lake at Squirrel Island & 319.136 & 30.915 & 350.051 & 319.163 & 31.684 & 350.847 \\
\hline 10 & 05129290 & $\begin{array}{l}\text { Gold Portage outlet from Kabetogama } \\
\text { Lake Near Ray, Minnesota }\end{array}$ & 309.624 & 30.361 & 339.985 & 309.646 & 31.151 & 340.797 \\
\hline 11 & 482611092483801 & $\begin{array}{l}\text { Kabetogama Lake, east end, near Old } \\
\text { Dutch Bay }\end{array}$ & 311.975 & 30.584 & 342.559 & 311.989 & 31.366 & 343.355 \\
\hline 12 & 482147092291701 & $\begin{array}{l}\text { Sand Point Lake below Harrison } \\
\text { Narrows near Crane Lake, Min- } \\
\text { nesota }\end{array}$ & 309.554 & 30.855 & 340.409 & 309.599 & 31.634 & 341.233 \\
\hline 13 & 482042092282501 & $\begin{array}{l}\text { Sand Point Lake above Harrison } \\
\text { Narrows Near Crane Lake, } \\
\text { Minnesota }\end{array}$ & 315.242 & 30.837 & 346.079 & 315.259 & 31.617 & 346.876 \\
\hline 14 & CNLM5 & Crane Lake at Crane Lake, Minnesota & 311.226 & 30.705 & 341.931 & 311.234 & 31.482 & 342.716 \\
\hline 15 & 481818092254201 & $\begin{array}{l}\text { Little Vermilion Lake above Little } \\
\text { Vermilion Narrows }\end{array}$ & 309.788 & 30.811 & 340.599 & 309.785 & 31.589 & 341.374 \\
\hline 16 & 05129115 & $\begin{array}{l}\text { Vermilion River near Crane Lake, } \\
\text { Minnesota }\end{array}$ & 326.747 & 30.585 & 357.332 & 326.773 & 31.371 & 358.144 \\
\hline 17 & AC4984 & $\begin{array}{l}\text { Cooperative Base Network Control } \\
\text { Station }\end{array}$ & 344.628 & 30.657 & 375.285 & 344.632 & 31.434 & 376.066 \\
\hline
\end{tabular}

${ }^{1}$ Elevation referenced to CGVD2013.

${ }^{2}$ Elevation referenced to NAVD 88. 
vertical crustal motion to processed baselines or estimated coordinates; corrections for vertical crustal motion may be plus or minus $( \pm) 0.003$ meter per year depending on the location within the study area (Henton and others, 2006; Craymer, 2006; Snay and Pearson, 2010). Ellipsoid heights obtained using USGS methods generally were higher than ellipsoid heights obtained using NRCan methods. Differences between methods ranged from -0.003 to $+0.045 \mathrm{~m}$, with a mean difference of $0.011 \mathrm{~m}$; furthermore, determined ellipsoid heights for NGS cooperative base network control station AC4984 (map number 17) closely approximate published values (National Geodetic Survey, 2015c). An ellipsoid height of 344.633 $\mathrm{m}$ was determined for station AC4984 during the last static GNSS survey done by the NGS in 1996 (National Geodetic Survey, 2015c). Ellipsoid heights of AC4984 determined using NRCan and USGS processing methods were $344.628 \mathrm{~m}$ and $344.632 \mathrm{~m}$, respectively. Offsets were developed using GNSS survey point elevations and surveyor leveling information (appendix 3).

A summary of streamgage offset values is presented in table 4. Site 8 is not included in table 4 because information available about the streamgage was not sufficient to develop an offset. Offsets presented in this report can be used in the evaluation of rule curves and in flood damage curves that fully assess the benefits of one regulation approach over another. In addition, offsets may be used to calibrate hydraulic models developed for four narrows that connect lakes of Namakan Reservoir, refine digital elevation models, and support modeling studies designed to assess the effects of rule curves on aquatic vegetation, benthic invertebrates, northern pike (Esox Lucius), and walleye (Sander vitreus). Because Canada recently adopted a national reference standard for elevations (Véronneau and others, 2014a, 2014b) that is based on a geoid model and compatible with GNSS positioning, the NRCan method was selected over the USGS method for developing offsets between published streamgage water levels and CGVD2013 elevations; furthermore, elevations referenced to CGVD2013 will be useful to other ongoing studies being completed by NRCan. Instantaneous water-level measurements in published streamgage format and instantaneous watersurface elevations in CGVD2013 are available in appendix 3. Subsequent comparisons of water-surface elevations among streamgages will be referenced to CGVD2013 and presented in metric units (meters).

Table 4. Offsets to convert published water levels to water-surface elevations referenced to the Canadian Geodetic Vertical Datum of 2013 for streamgages in Rainy Lake, Namakan Reservoir, and selected rivers.

[Published data type, descriptor of type of water-level data published at a streamgage; Offset, the value to be added or subtracted to water-level data to convert published streamgage data to elevations in Canadian Geodetic Vertical Datum of 2013; EC, Environment Canada; Elevation, water levels are published as elevations referenced to a previously specified vertical datum; USGS, U.S. Geological Survey; Local datum, an arbitrary datum used to simplify data display when publishing water-level data for streamgages; no., number; USACE, U.S. Army Corps of Engineers]

\begin{tabular}{|c|c|c|c|c|c|c|c|}
\hline \multirow{2}{*}{$\begin{array}{c}\text { Map } \\
\text { number } \\
\text { (fig. 1) }\end{array}$} & \multirow{2}{*}{ Station number } & \multirow{2}{*}{ Station name } & \multirow{2}{*}{ Agency } & \multirow{2}{*}{$\begin{array}{l}\text { Published } \\
\text { data type }\end{array}$} & \multirow{2}{*}{$\begin{array}{l}\text { Published } \\
\text { units }\end{array}$} & \multicolumn{2}{|c|}{ Offset } \\
\hline & & & & & & Meter & Foot \\
\hline 1 & 05PC021 & Rainy River at Rainy River & EC & Elevation & Meter & -0.361 & -1.18 \\
\hline 2 & 05133500 & Rainy River at Manitou Rapids, Minnesota & USGS & Local datum & Foot & +323.475 & $+1,061.27$ \\
\hline 3 & 05PC024 & Rainy River at Pithers Point site no. 1 & $\mathrm{EC}$ & Elevation & Meter & -0.637 & -2.09 \\
\hline 4 & 05РВ007 & Rainy Lake near Fort Frances & $\mathrm{EC}$ & Elevation & Meter & -0.608 & -1.99 \\
\hline 5 & 05РB023 & Rainy Lake at Northwest Bay & EC & Local datum & Meter & +328.315 & $+1,077.15$ \\
\hline 6 & 05РВ024 & Rainy Lake near Bear Pass & $\mathrm{EC}$ & Elevation & Meter & -0.599 & -1.97 \\
\hline 7 & 05РB014 & Turtle River near Mine Centre & EC & Local datum & Meter & +344.176 & $+1,129.19$ \\
\hline 9 & 05PA013 & Namakan Lake at Squirrel Island & $\mathrm{EC}$ & Elevation & Meter & -0.613 & -2.01 \\
\hline 10 & 05129290 & $\begin{array}{l}\text { Gold Portage outlet from Kabetogama } \\
\text { Lake Near Ray, Minnesota }\end{array}$ & USGS & Local datum & Foot & +334.701 & $+1,098.10$ \\
\hline 11 & 482611092483801 & $\begin{array}{l}\text { Kabetogama Lake, east end, near Old } \\
\text { Dutch Bay }\end{array}$ & USGS & Local datum & Foot & +334.384 & $+1,097.06$ \\
\hline 12 & 482147092291701 & $\begin{array}{l}\text { Sand Point Lake below Harrison Narrows } \\
\text { near Crane Lake, Minnesota }\end{array}$ & USGS & Elevation & Foot & -0.820 & -2.69 \\
\hline 13 & 482042092282501 & $\begin{array}{l}\text { Sand Point Lake above Harrison Narrows } \\
\text { Near Crane Lake, Minnesota }\end{array}$ & USGS & Elevation & Foot & -0.802 & -2.63 \\
\hline 14 & CNLM5 & Crane Lake at Crane Lake, Minnesota & USACE & Elevation & Foot & -0.597 & -1.96 \\
\hline 15 & 481818092254201 & $\begin{array}{l}\text { Little Vermilion Lake above Little Vermil- } \\
\text { ion Narrows }\end{array}$ & USGS & Elevation & Foot & -0.808 & -2.65 \\
\hline 16 & 05129115 & $\begin{array}{l}\text { Vermilion River near Crane Lake, } \\
\text { Minnesota }\end{array}$ & USGS & Local datum & Foot & +352.769 & $+1,157.38$ \\
\hline
\end{tabular}




\section{Survey Comparisons}

Offsets developed to correct measured water-level data to elevations above sea level referenced to CGVD2013 were applied to collected water-level data from active and discontinued streamgages in the study area. Daily mean water levels during the survey period were compared among active streamgages on Namakan Reservoir, Rainy Lake, and surveyed rivers (fig. 1). In addition, monthly mean water levels from 2012 were compared for all active and discontinued streamgages in Namakan Reservoir. Monthly mean water levels were used to reduce variability associated with temporary installations, and data from 2012 were used because 2012 represents the most recent period when all active and discontinued streamgages ran simultaneously.

\section{Namakan Reservoir}

Active, continuous streamgages for Namakan Reservoir operate at Crane Lake (map number 14; USACE station CNLM5), the Gold Portage outlet of Kabetogama Lake (map number 10; USGS station 05129290), and Squirrel Island near the outlet of Namakan Lake (map number 9; EC station 05PA013) (fig. 1). Boxplots of water-surface elevations (referenced to CGVD2013) during the data collection period (October 5-9, 2014) at active streamgages in Namakan Reservoir are presented in figure 3. Mean water-surface elevations decreased from upstream to downstream among all three stations.

\section{Rainy Lake}

Active streamgages in Rainy Lake operate near Bear Pass (map number 6; EC station 05PB024), at Northwest Bay (map number 5; EC station 05PB023), and near Fort Frances (map number 4; EC station 05PB007) (fig. 1). Water-surface elevation data (referenced to CGVD2013) for the data collection period (October 5-9, 2014) at active streamgages in Rainy Lake are presented in figure 4. Mean water-surface elevations during the data collection period were similar among all three stations.

\section{Rivers}

Rivers with active streamgages surveyed in this study include the Vermilion, Turtle, and Rainy Rivers (fig. 1). A bar chart of mean water-surface elevations (referenced to CGVD2013) for active river streamgages surveyed in this study are presented in figure 5; mean water-surface elevations were determined by taking the mean of continuous water level data collected October 5-9, 2014, at each streamgage and applying the appropriate offsets. Vermilion River near Crane Lake, Minnesota (map number 16; USGS station 05129115) and the Turtle River near Mine Centre (map number 7; EC station 05PB014) represent inflow streamgages to Namakan Reservoir and Rainy Lake, respectively. Water-surface elevations at the inflow streamgages are substantially higher than the water-surface elevations of Namakan Reservoir (fig. 3) and Rainy Lake (fig. 4). Starting at the outlet of Rainy Lake and moving downstream towards Lake of the Woods, Rainy River streamgages were surveyed at Pithers Point (map number 3; EC station 05PC024), Manitou Rapids (map number 2; USGS station 05133500), and the town of Rainy River, Ontario (map number 1; EC station 05PC021) (fig. 1). Water-surface elevations at the outlet of Rainy Lake (map number 3; EC station 05PC024) were slightly lower in elevation than Rainy Lake (fig. 4), and a substantial drop in elevation (more than $10 \mathrm{~m}$ ) was observed between Pithers Point (map number 3; EC station 05PC024) and Manitou Rapids (map number 2; USGS station 05133500). A smaller drop in elevation (about $2 \mathrm{~m}$ ) was observed between Manitou Rapids (map number 2; USGS station 05133500) and the town of Rainy River, Ontario (map number 1; EC station 05PC021).

\section{Namakan Reservoir Data}

Because surveyed temporary streamgages were discontinued, boxplots of monthly water-level data collected in 2012 were compared for all active and discontinued streamgages in the Namakan Reservoir (fig. 1). Boxplots of monthly water-surface elevations referenced to CGVD2013 for May through September of 2012 are presented in figure 6. Elevations generally decrease from upstream to downstream, with the most notable exception being the temporary indexvelocity streamgage used to measure flow between Namakan and Kabetogama Lakes (map number 11; USGS station 482611092483801). In addition, water-surface elevations for the temporary streamgage at Sand Point Lake below Harrison Narrows (map number 12; USGS station 482147092291701) seem to be lower than elevations at the outlet sites at Squirrel Island (map number 9; EC station 05PA013) and Gold Portage (map number 10; USGS station 05129290).

The observed water levels at discontinued streamgages 482611092483801 (map number 11) and 482147092291701 (map number 12) do not make sense hydrologically given the direction of flowing water, which indicates that the transducers may have shifted on the lake bottoms or that initial water levels may have been established incorrectly. A time mismatch could have happened when programming the water levels into the transducers based on a measurement from a reference point of known elevation. During windy and wavy conditions, water levels can vary by as much as $\pm 0.060 \mathrm{~m}$ (U.S. Geological Survey, 2015), and there is a delay associated with programming water levels into the transducers. If a reference point is measured during the trough of the waves and is applied to the transducer during the peak of the waves, then the transducer readings will read consistently low. Similarly, if 


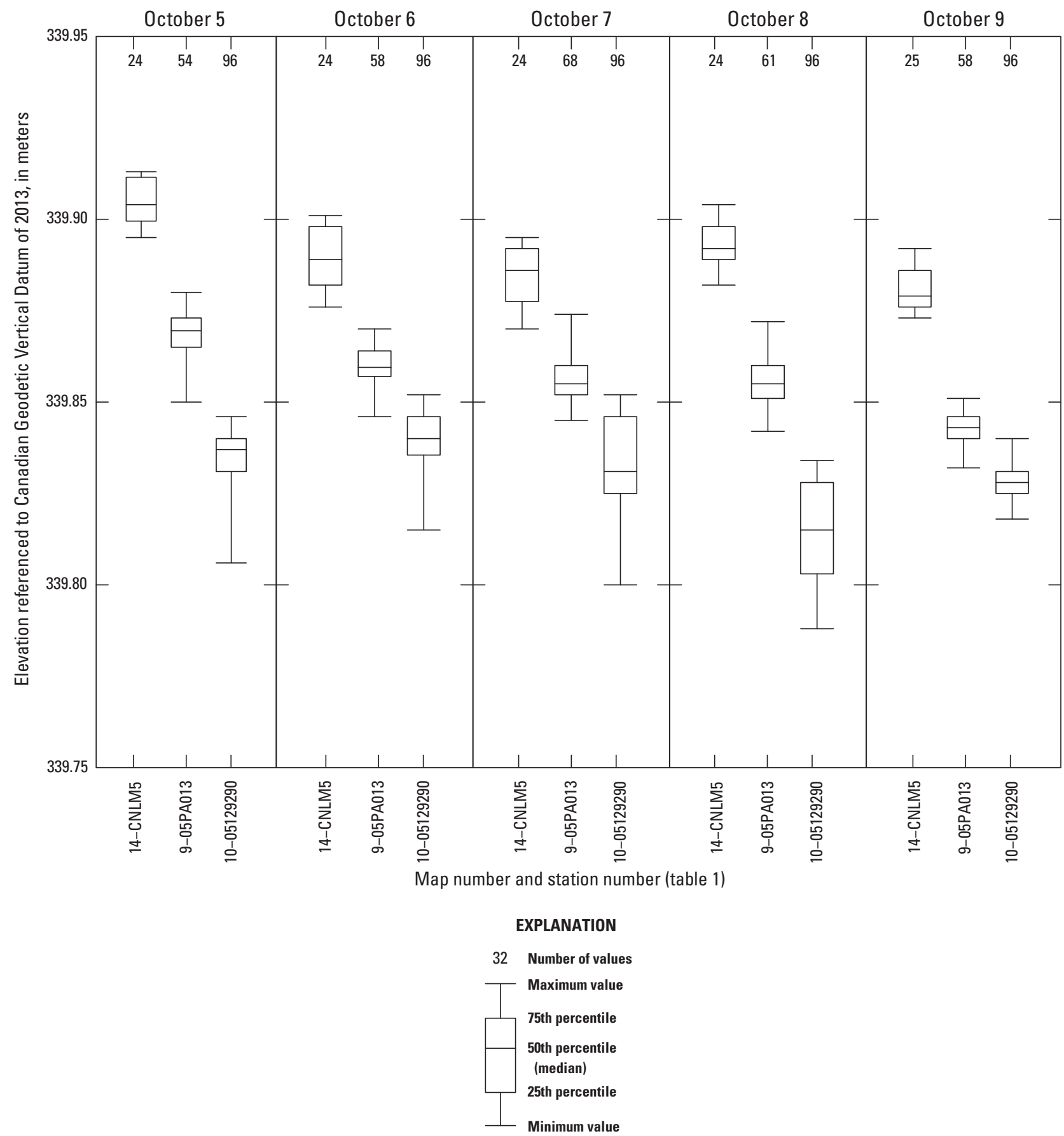

Figure 3. Water-surface elevation data referenced to the Canadian Geodetic Vertical Datum of 2013 for the data collection period (October 5-9, 2014) at active streamgages in Namakan Reservoir, which are identified using map and station numbers associated with data in table 1.

a reference point is measured during the peak of the waves and is applied to the transducer during the trough of the waves, then the transducer will read consistently high.

Published daily mean water-surface elevations (referenced to NAVD 88) from 2012 were compared for the two discontinued streamgages on Sand Point Lake (map numbers 12 and 13; USGS stations 482147092291701 and
482042092282501 , respectively) to further address the hydrologic discrepancy observed at USGS station 482147092291701 (map number 12; fig. 7). Changes in water levels associated with precipitation and changes in dam regulation track perfectly between the two streamgages (fig. 7), and water-surface elevations measured manually during site visits that happened on the same day were identical or demonstrated substantial 


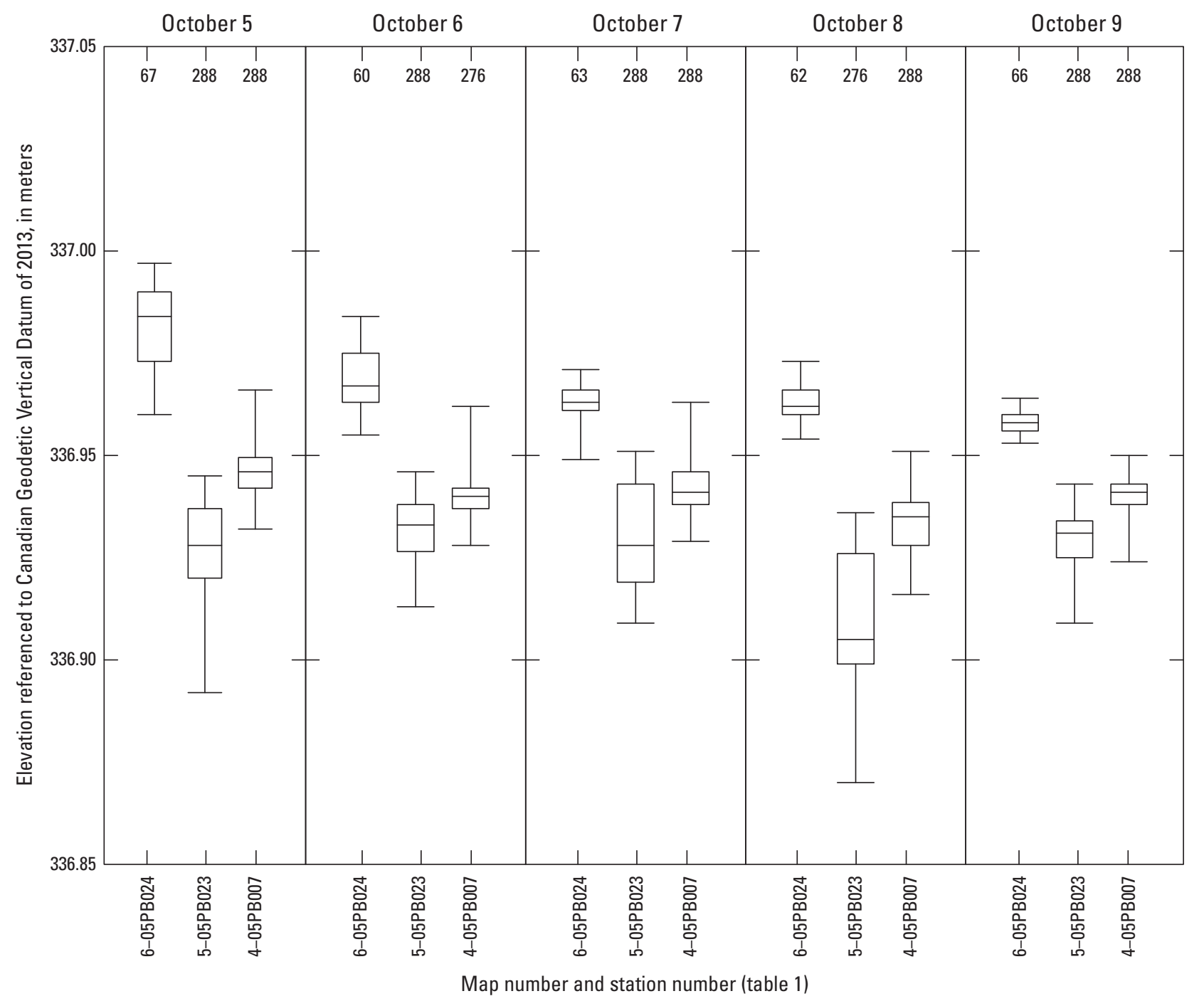

EXPLANATION

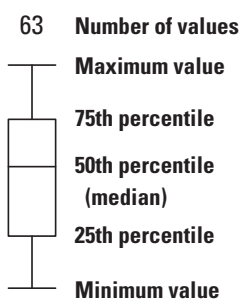

Figure 4. Water-surface elevation data referenced to the Canadian Geodetic Vertical Datum of 2013 for the data collection period (October 5-9, 2014) at active streamgages in Rainy Lake, which are identified using map and station numbers associated with data in table 1. 


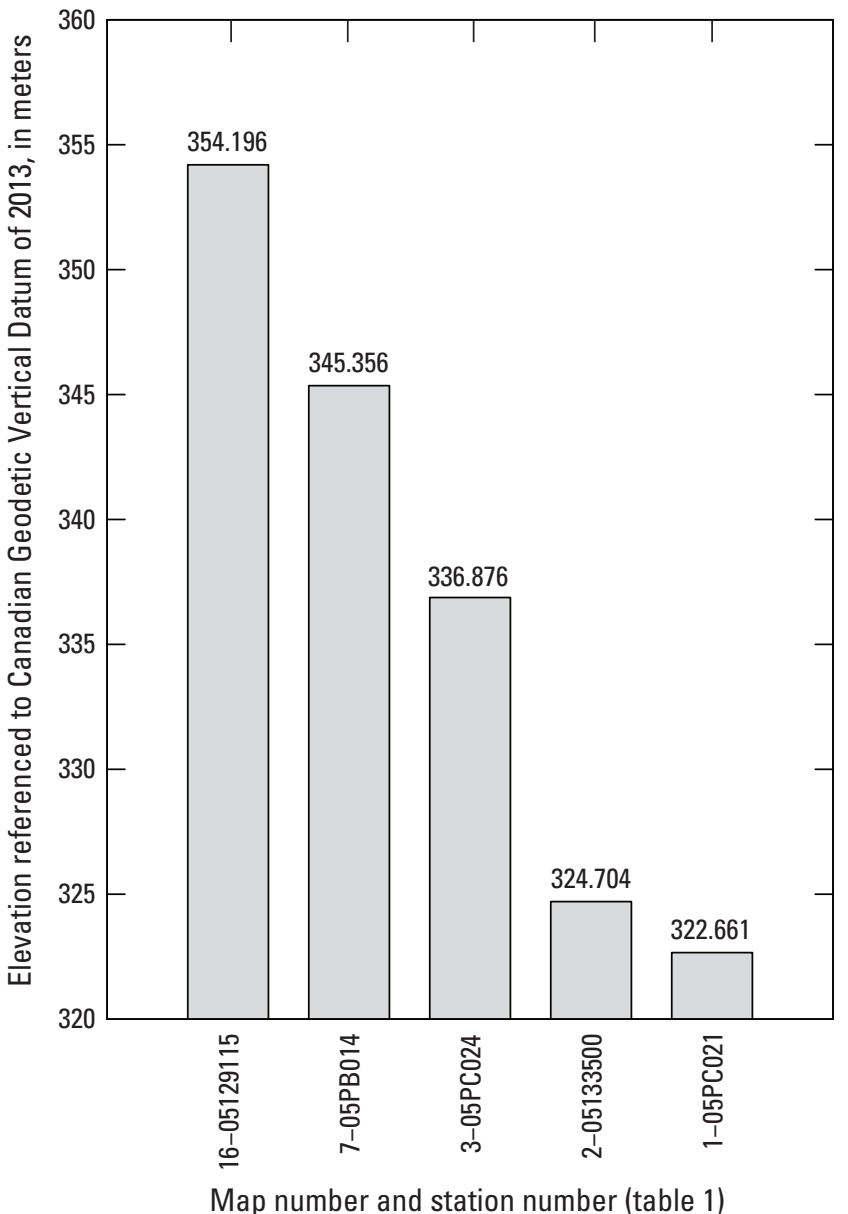

Figure 5. Mean water-surface elevations referenced to the Canadian Geodetic Vertical Datum of 2013 for the data collection period (October 5-9, 2014) at active streamgages on the Vermilion (map number 16; station 05129115), Turtle (map number 7; 05PB014), and Rainy (map numbers 1, 2, and 3; stations 05PC021, 05133500 and 05PC024, respectively) Rivers; streamgages are identified using map and station numbers associated with data in table 1.

overlap in observed ranges (U.S. Geological Survey, 2015). These data indicate that a time mismatch did not cause the water-surface elevation differences between the two streamgages observed in figure 6 . The observed differences likely are attributable to variability associated with collected satellite data or variability in the instantaneous water level measured during the GNSS survey, which was used to develop the offset that corrects collected water-level data to elevations referenced to CGVD2013.

Data are insufficient to similarly address if a time mismatch happened at USGS station 482611092483801 (map number 11). Possible causes for the observed hydrologic discrepancy could include a time mismatch, variability in the collected satellite data, and variability in the instantaneous water level measured during the GNSS survey, which was used to develop the offset that corrects collected water-level data to elevations referenced to CGVD2013. For active streamgages in the Namakan Reservoir, data collected in 2012 (fig. 6) showed a similar pattern to data collected during 2014 surveys when both datasets were corrected to reference CGVD2013 (fig. 3), indicating that active streamgages have remained stable with time. Finally, five of the seven surveyed streamgages (active and discontinued) in Namakan Reservoir demonstrated water-surface elevations that consistently decreased from upstream to downstream when offsets were applied to water-level data collected in 2012.

\section{Limitations of the Study}

Several limitations should be considered when applying results obtained from analyses presented in this report. Collected satellite data were compared among all sites simultaneously in order to minimize the overall error in the survey. In addition, elevations obtained for reference marks in this study are referenced to specified ellipsoid and geoid models, so the elevations presented in this report should not be considered absolute elevations. Geoid models CGG2013 and 12A were applied to ellipsoid heights presented in table 3 in order to obtain elevations referenced to CGVD2013 and NAVD 88 , respectively; however, only elevations referenced to CGVD2013 were used to develop offsets presented in table 4.

Streamgage datum offsets were developed using instantaneous water-level measurements; therefore, presented offsets do not account for variability associated with wind, wave action, dam regulation, and other factors. At active streamgages, continuous water-level data can be used to examine the relations among water-surface elevations at streamgages and to evaluate the accuracy of presented offsets; however, similar comparisons could not be made to examine variability with time at discontinued streamgage locations without going back to data collected in 2012. Comparing 2012 water-level data corrected to elevations referenced to CGVD2013, elevations for two streamgages (USGS stations 482147092291701 and 482611092483801 ) that were discontinued in October 2012 did not make hydrologic sense compared to other streamgages (fig. 6); therefore, caution should be used when applying presented streamgage offsets to discontinued, temporary streamgages. If discrepancies between water-surface elevations at discontinued streamgages and nearby active streamgages demonstrate consistency during the entire period of overlapping measured record, then data corrections could be applied to water-level data collected at discontinued streamgages in order to incorporate the data into modeling applications and rule curve evaluations; however, the described analyses are beyond the scope of this report. 


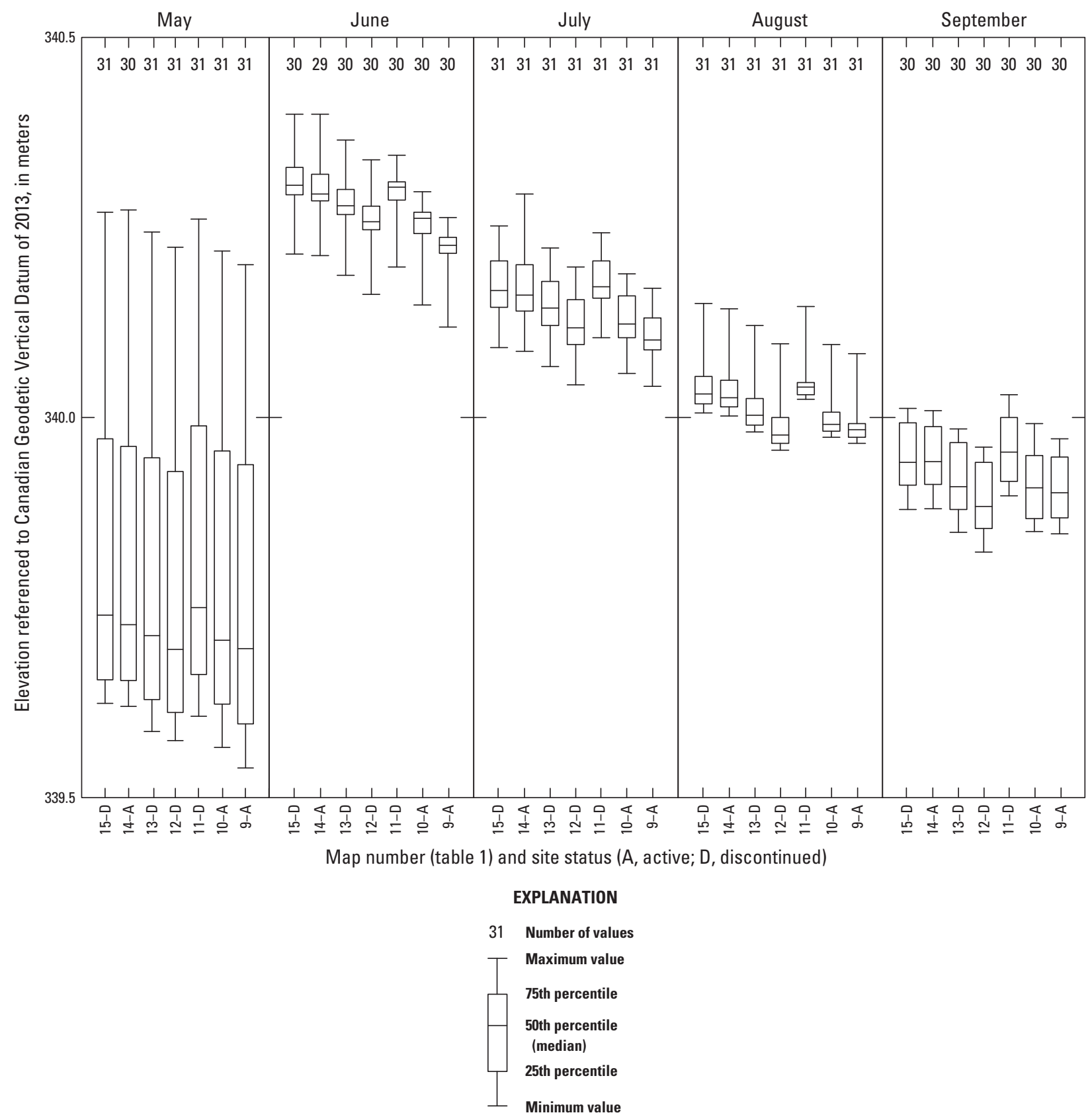

Figure 6. Monthly water-surface elevation data for all active and discontinued streamgages in Namakan Reservoir during the open water period of 2012, converted from streamgage datums to the Canadian Geodetic Vertical Datum of 2013 using offsets presented in table 4; streamgages are identified using map numbers associated with data in table 1. 


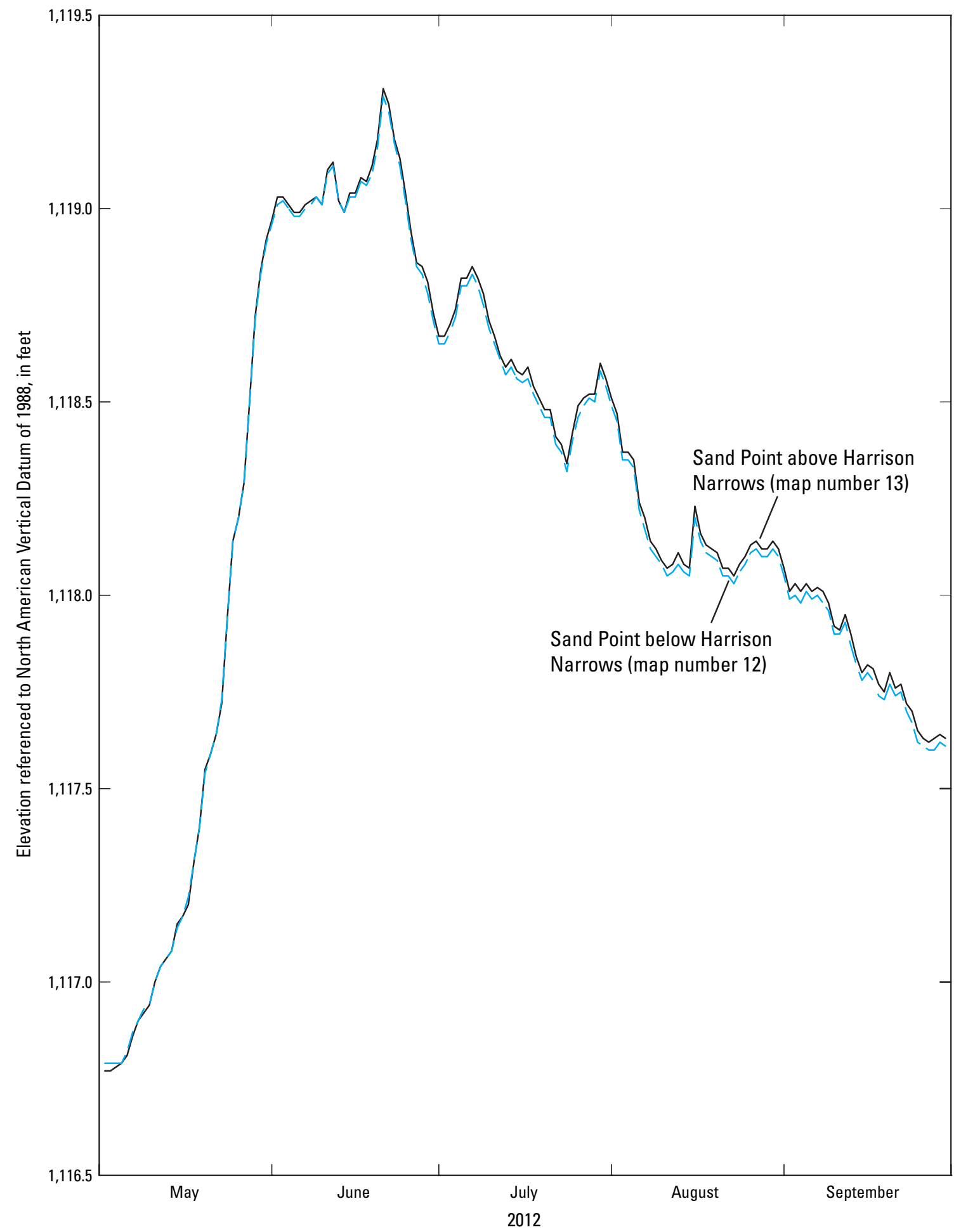

Figure 7. Published mean daily water-surface elevations (referenced to the North American Vertical Datum of 1988) for discontinued U.S. Geological Survey water-level streamgages on Sand Point Lake above (map number 13; station 482042092282501) and below (map number 12; station 482147092291701) Harrison Narrows in 2012 (data from U.S. Geological Survey, 2015). 


\section{Summary}

Continuously recording water-level streamgages in Rainy Lake and Namakan Reservoir are used to regulate water levels according to rule curves established in 2000 by the International Joint Commission; however, streamgage water levels were referenced to a variety of vertical datums, confounding efforts to model the flow of water through the system, regulate water levels during periods of high inflow, and evaluate the effectiveness of the rule curves. In October 2014, the U.S. Geological Survey, Natural Resources Canada, International Joint Commission, and National Park Service began a joint field study with the goal of obtaining precise elevations referenced to a uniform vertical datum for all reference marks used to establish water-level streamgages throughout Rainy Lake and Namakan Reservoir.

This report was prepared by the U.S. Geological Survey in cooperation with Natural Resources Canada, the International Joint Commission, and the National Park Service. The purposes of this report are to (1) describe the field surveys used to collect Global Navigation Satellite System (GNSS) data for 16 streamgage reference marks in the Rainy River Basin, (2) describe how collected GNSS data were processed to determine water-surface elevations for all streamgages surveyed in this study, (3) present corrections to convert waterlevel data previously collected at the streamgages to watersurface elevations referenced to a uniform vertical datum, and (4) outline factors to consider when applying corrections to previously collected water-level data.

Three field crews deployed static GNSS receivers over 16 reference marks colocated with active and discontinued water-level streamgages throughout Rainy River, Rainy Lake, Namakan Reservoir, and select tributaries of Rainy Lake and Namakan Reservoir. A static GNSS receiver also was deployed over a National Geodetic Survey cooperative base network control station that was used as a quality-control reference mark, resulting in a total of 17 surveyed reference marks in this study. Satellite data were collected simultaneously during a 5-day period and processed independently by the U.S. Geological Survey and Natural Resources Canada to obtain accurate positioning and elevations for the 17 reference marks. Deployment times for GNSS receivers ranged from 29 to 68 hours, with a mean deployment time of 46 hours. Satellite data were processed using two different methods, and the results were compared as a measure of quality assurance. Results were similar between compared methods. Processed satellite data were used to convert published water levels to elevations referenced to the Canadian Vertical Datum of 2013 in order to compare water-surface elevations in a uniform vertical datum throughout the study area.

Offsets were applied to water-level data from surveyed streamgages to further evaluate the accuracy and utility of updated reference mark elevations presented in this study. In this report, an "offset" refers to the correction that needs to be applied to published data from a particular streamgage to produce elevation data referenced to a specified vertical datum. Daily mean water levels from active streamgages surveyed in this study were converted to water-surface elevations referenced to the Canadian Geodetic Vertical Datum of 2013; graphical comparisons of water-surface elevations for streamgages in Namakan Reservoir, Rainy Lake, and selected rivers are presented. Active, permanent streamgages demonstrated strong hydrologic agreement throughout Namakan Reservoir, Rainy Lake, and surveyed river streamgages; water-surface elevations consistently decreased from upstream to downstream. Discontinued, temporary streamgages had more variability and less hydrologic agreement among water-surface elevations than active, permanent streamgages. Offsets presented in this report can be used in the evaluation of rule curves and in flood damage curves that fully assess the benefits of one regulation approach over another. In addition, offsets may be used to calibrate hydraulic models developed for four narrows that connect lakes of Namakan Reservoir, refine a digital elevation model, and support modeling studies designed to assess the effects of rule curves on aquatic vegetation, benthic invertebrates, northern pike, and walleye.

\section{References Cited}

Beattie, D.S., 1987, Program GHOST User Documentation: Ottawa, Ontario, Canada, Geodetic Survey of Canada, August 1987.

Canadian Geodetic Survey, 2003, Standard operational procedure-Static GPS surveys: Ottawa, Canadian Geodetic Survey, Natural Resources Canada, document number GGN-04, v. 1.0.

Canadian Geodetic Survey, 2013, Standard operational procedure-Field operations: Ottawa, Canadian Geodetic Survey, Natural Resources Canada, document number GGN-18, v. 1.4 .

Christensen, V.G., Maki, R.P., and Kiesling, R.L., 2013, Evaluation of internal loading and water level changesImplications for phosphorus, algal production, and nuisance blooms in Kabetogama Lake, Voyageurs National Park, Minnesota: Lake and Reservoir Management, v. 29, no. 3, p. 202-215. [Also available at http://dx.doi.org/10.1080/104 02381.2013.831148.]

Craymer, M.R., 2006, The evolution of NAD83 in Canada: Geomatica, v. 60, no. 2, p. 151-164. [Also available at http://www.naref.org/transf/nad83_geomatica2006.pdf.]

Craymer, M.R., Henton, J.A., Piraszewski, M., and Lapelle, E., 2011, An updated GPS velocity field for Canada: Eos Transactions, v. 92, no. 51, American Geophysical Union, Fall Meeting 2011, Abstract G21A-0793. 
Dach, R., Hugentobler, U., Fridez, P., and Meindl, M., eds., 2007, Bernese GPS software version 5.0: Bern, Switzerland, University of Bern, Astronomical Institute.

Dach, R., and Walser, P., 2015, Bernese GNSS software version 5.2-Tutorial: Bern, Switzerland, University of Bern, Astronomical Institute.

Densmore, B.K., Strauch, K.R., and Ziegeweid, J.R., 2013, Hydrographic surveys of four narrows within the Namakan reservoir system, Voyageurs National Park, Minnesota, 2011: U.S. Geological Survey Data Series 792, 12 p. [Also available at http://pubs.usgs.gov/ds/792/.]

Environment Canada, 2015, Wateroffice: Environment Canada Web page, real-time hydrometric data map search, accessed November 30, 2015, at http://wateroffice.ec.gc.ca/.

Georgiadou, Y., and Kleusberg, A., 1988, On carrier signal multipath effects in relative GPS positioning: Manuscripta Geodaetica, v. 13, p. 172-179.

Henton, J.A., Craymer, M.R., Dragert, H., Mazzoti, S., Ferland, R., and Forbes, D.L., 2006, Crustal motion and deformation monitoring of the Canadian landmass: Geomatica v. 60, no. 2, p. 173-191.

Huang, J. and Véronneau, M., 2013, Canadian gravimetric geoid model 2010: Journal of Geodesy, v. 87, no. 8, p. 771-79. [Also available at http://dx.doi.org/10.1007/ s00190-013-0645-0.]

International Rainy Lake Board of Control, 1999, Final reportReview of the IJC order for Rainy and Namakan Lakes: St. Paul, Minn., and Burlington, Ontario, Canada, International Rainy Lake Board of Control, accessed September 19, 2012, at http://www.ijc.org/rel/boards/rainylake/19991026_e.pdf.

Kallemeyn, L.W., Holmberg, K.L., Perry, J.A., and Odde, B.Y., 2003, Aquatic synthesis for Voyageurs National Park: U.S. Geological Survey Information and Technology Report 2003-001, 95 p. [Also available at http://pubs.er.usgs.gov/ publication/itr030001/.]

Kenney, T.A., 2010, Levels at gaging stations: U.S. Geological Survey Techniques and Methods, book 3, chap. A19, 60 p. [Also available at http://pubs.usgs.gov/tm/tm3A19/.]

Li, Xiong, and Götze, H.J., 2001, Tutorial-Ellipsoid, geoid, gravity, geodesy, and geophysics: Geophysics, v. 66, no. 6, p. 1660-1668. [Also available at http://dx.doi. org/10.1190/1.1487109.]

Milbert, D.G., and Smith D.A., 1996, Converting GPS height into NAVD88 elevation with the Geoid96 geoid height model: GIS LIS-International Conference, v. 1, p. 681-692 [Also available at http://www.ngs.noaa.gov/PUBS_LIB/ gislis96.html.]
National Geodetic Survey, 2012, The National Adjustment of 2011 Project: National Geodetic Survey Web page, accessed February 2, 2015, at http:/www.ngs.noaa.gov/web/surveys/ NA2011/.

National Geodetic Survey, 2014a, Continuously Operating Reference Station (CORS): National Geodetic Survey Web page, accessed February 2, 2015, at http:/www.ngs.noaa. gov/CORS/.

National Geodetic Survey, 2014b, OPUS_-Online positioning user service: National Geodetic Survey Web page, accessed February 2, 2015, at http://www.ngs.noaa.gov/OPUS/about. jsp.

National Geodetic Survey, 2014c, OPUS Projects: National Geodetic Survey, accessed February 2, 2015, at http://www. ngs.noaa.gov/OPUS-Projects/OpusProjects.shtml.

National Geodetic Survey, 2015a, PAGES software, table of contents: National Geodetic Survey Web page, accessed February 15, 2015, at http://www.ngs.noaa.gov/GRD/GPS/ DOC/toc.html.

National Geodetic Survey, 2015b, GEOID12A: National Geodetic Survey Web page, accessed October 16, 2015, at http://www.ngs.noaa.gov/GEOID/GEOID12A/.

National Geodetic Survey, 2015c, Geodetic Data Sheet, GSID Station \# 28366: National Geodetic Survey Web page, accessed February 15, 2015, at ftp://ftp.olmweb.dot.state. mn.us/Geod/PDF\%20Metric\%20Sheet/M_GSID_28366. pdf.

Natural Resources Canada, 2016, Canadian Active Control System (CACS): Natural Resources Canada Web page, accessed May 11, 2016, at https://webapp.geod.nrcan.gc.ca/ geod/data-donnees/cacs-scca.php.

Rydlund, P.H., Jr., and Densmore, B.K., 2012, Methods of practice and guidelines for using survey-grade global navigation satellite systems (GNSS) to establish vertical datum in the United States Geological Survey: U.S. Geological Survey Techniques and Methods Report, book 11, chap. D1, 120 p. with appendixes [Also available at http://pubs. er.usgs.gov/publication/tm11D1.]

Snay, R., and Pearson, C., 2010, Coping with tectonic motion: American Surveyor, v. 7, no. 9, p. 28-42.

Stevenson, D. and Thompson, A.F., 2013, Namakan chain of lakes pinch point modelling: report prepared for the International Joint Commission, Rainy Lake Board of Control, $87 \mathrm{p}$.

U.S. Army Corps of Engineers, 2015, St. Paul District Water Control Center: U.S. Army Corps of Engineers Web page, real time water resources data, accessed November 30, 2015, at http://www.mvp-wc.usace.army.mil/dcp/. 
U.S. Geological Survey, 2015, USGS surface-water data for the Nation: U.S. Geological Survey National Water Information System Web page, accessed November 30, 2015, at http://waterdata.usgs.gov/nwis/sw.

Véronneau, M., Huang, J., Smith, D.A., and Roman, D.R., 2014a, Canada's new vertical datum-CGVD2013: xyHT, October 2014, p. 43-45, accessed May 16, 2016, at http:// www.xyht.com/surveying/canadas-new-vertical-datum$\operatorname{cgvd} 2013 /$.
Véronneau, M., Huang, J., Smith, D.A., and Roman, D.R., 2014b, CGVD2013, part 2: xyHT, November 2014, p. $41-43$.

Zilkoski, D.B., Richards, J.H., and Young, G.M., 1992, Special report results of the general adjustment of the North American Vertical Datum of 1988: Surveying and Land Information Systems, v. 52, no. 3, p. 133-149. 
Appendixes 1-3 


\title{
Appendix 1. Global Navigation Satellite System Data Collection Information
}

Appendix 1 is available for download as an Excel $^{\circledR}$ file at http://dx.doi.org/10.3133/sir20165109.

This appendix contains data collection information for the Global Navigation Satellite System (GNSS) as a Microsoft® Excel spreadsheet. The first worksheet (tab) in the spreadsheet is table 1-1, which provides a summary of collected satellite data for the 16 streamgage reference marks and the 1 National Geodetic Survey control station surveyed in this study. The other worksheets (tabs) in the spreadsheet contain the log files from the GNSS surveys for each of the reference marks and are presented in order of map number and are named according to the station numbers (table 1-1).

Table 1-1. Summary of collected satellite data for 16 streamgage reference marks and 1 National Geodetic Survey cooperative base network control station surveyed in this study.

\section{Appendix 2. Processing of Raw Data Collected for 16 Streamgage Reference Marks and 1 National Geodetic Survey Cooperative Base Network Control Station Using Global Navigation Satellite Systems}

Appendix 2 is available for download as an Excel ${ }^{\circledR}$ file at http://dx.doi.org/10.3133/sir20165109.

This appendix contains the data processing files collected for reference marks at the 16 streamgages and the National Geodetic Survey control station using Global Navigation Satellite Systems (GNSS) as a zipped file. The data were processed by Natural Resources Canada (NRCan) and the U.S. Geological Survey (USGS) using different methods. The zipped file contains a READ_ME file with information about the data processing files. The zipped file contains two folders (NRCan_Processing_Files and USGS_Processing_Files) for the processing file outputs from NRCan and the USGS, respectively.

\section{Appendix 3. Surveyor Level Loop Information for Selected Sites}

Appendix 3 is available for download as an Excel $^{\circledR}$ file at http://dx.doi.org/10.3133/sir20165109.

This appendix contains surveyor level loop information as a Microsoft $®$ Excel spreadsheet for the nine streamgage sites with reference marks that could not be surveyed directly using global navigation satellite systems. The first worksheet (tab) in the spreadsheet is titled "Read_Me" and provides a summary of the spreadsheet. The other worksheets (tabs) in the spreadsheet contain the surveyor level loop information for each of the nine sites and are presented in order of map number and are named according to the station numbers (see the "Introduction" section, table 1).

\author{
Publishing support provided by: \\ Rolla Publishing Service Center \\ For more information concerning this publication, contact: \\ Director, USGS Minnesota Water Science Center \\ 2280 Woodale Drive \\ Mounds View, Minnesota 55112 \\ (763) 783-3100
}

Or visit the Minnesota Water Science Center Web site at:

http://mn.water.usgs.gov/ 



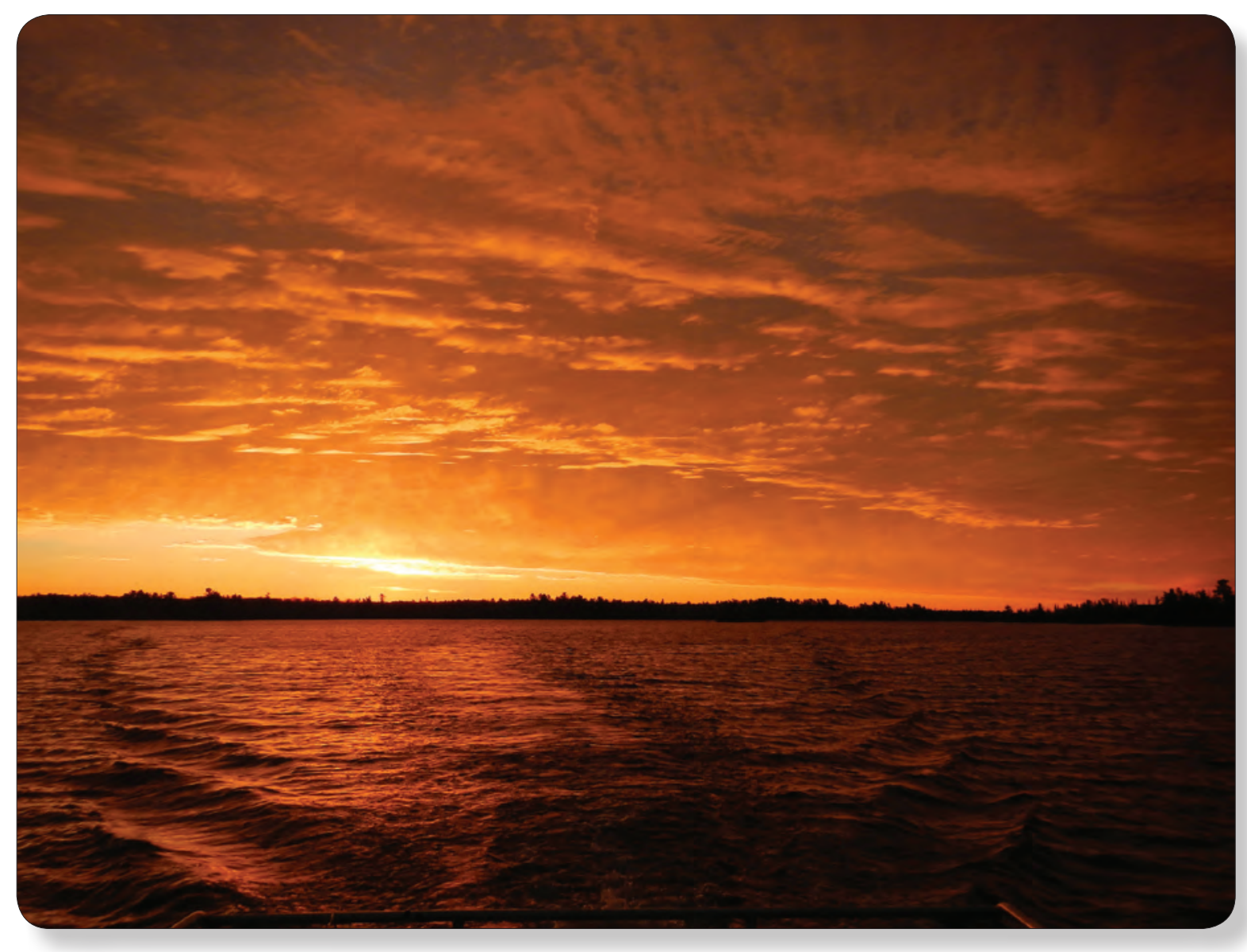

